\title{
New Lights on the Anonymus Londiniensis Papyrus
}

\author{
Jordi Crespo Saumell
}

The Anonymus Londiniensis is a masterpiece in the History of Philosophy and Science. In this article my aim is to give an updated and critical account of the papyrus, and to expound certain arguments to support the thesis that two works now lost served as the basis for the Londiniensis: one part of the second section of the Londiniensis papyrus was mainly shaped according to an Aristotelian text, whereas the third section of the papyrus relied on a different source.

\section{Introduction}

The Anonymus Londiniensis is a Greek literary papyrus ${ }^{1}$ of medical content written at a certain point during the last quarter of the first century $\mathrm{CE}^{2}$. The 39 preserved columns in the papyrus, containing an average of 49 lines (c. 1920 lines in total), turn the Anonymus Londiniensis into the longest papyrus of its kind to come down to us. From its discovery to the present the Londiniensis papyrus has been subject to 4 different editions and to several translations into modern languages. Thus, the editio princeps by H. Diels in 1893 would eventually be used by H. Beckh and F. Spät and W. H. S. Jones in their respective translations into German (1896) and into English (1947). In 2011 D. Manetti published a new edition of the papyrus without translation; and in 2014 and 2016 two new editions of the Londiniensis were published by A. Ricciardetto, both accompanied with a French translation. Notwithstanding the partial editions and transla-

${ }^{1}$ P. Brit. Lond. inv. $137=\mathrm{MP}^{3} 2339$ or LDAB 3964.

${ }^{2}$ Manetti (1994), p. 57. From a paleographical point of view, the way the scribe of Anon. Lond. writes the letter alpha tallies with the typology $16 \alpha$ established for documentary papyri. Cfr. Harrauer (2010), p. 146. Albeit this sole hint does not unmistakably mean that the Londiniensis papyrus was written at some point in the third quarter of the first century CE, this chronology has been confirmed by way of other comparative arguments. Dorandi (2016), p. 199. Thus, it has been adduced that the "main hand" on the recto of Anon. Lond. shares many points in common either with the first $\left(\mathrm{m}^{1}\right)$ or the fourth hand $\left(\mathrm{m}^{4}\right)$ distinguished in P. Lit. Lond. 108, Brit.Lib. inv. $131^{\mathrm{v}}=\mathrm{MP}^{3} 163$ or LDAB 391 ; that is to say, the papyrus of the later $1^{\text {st }}$ earlier $2^{\text {nd }}$

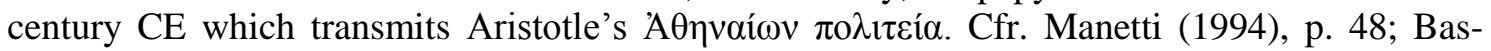
tianini (1995), pp. 32-3; Cavallo (2008), pp. 57-8; Del Corso (2008), p. 17; Ricciardetto (2016), p. CXXVIII. 
tions of some passages in the Anonymus papyrus by D. Manetti, either in the $C P F$ or in some of her several contributions on the issue at hand, there was no full translation of the text(s) in the Londiniensis into Italian ${ }^{3}$.

But if I said 'text(s)' it is due to the fact that the Londiniensis comprises more than a single writing. As regards "the main writing", the contents on the recto of the papyrus have been generally divided into three different sections ${ }^{4}$. The first one ${ }^{5}$, nosological, consists of a list of definitions of medical concepts about disease. The second section $^{6}$, etiological, recollects the opinions on the causation of disease held by 20 ancient authors ${ }^{7}$, seven of them unattested elsewhere ${ }^{8}$. Furthermore, all the etiological theories reported in the second section neatly fall into two major criteria: first, are set out those opinions attributing disease to the residues of food $(\pi \varepsilon \rho 1 \sigma \sigma \omega ́ \mu \alpha \tau \alpha)^{9}$; and, second, starting with a long paraphrase of the Timaeus ${ }^{10}$, the opinions of the authors who put the causation of disease down to the constitutive elements in the body $(\sigma \tau o \text { } \chi \varepsilon \tilde{\varepsilon} \alpha)^{11}$. In the third section ${ }^{12}$, physiological, the scribe addresses some questions concerning the distribution of air and nutrients in the body, before moving on to a discussion on the theory of the emanations.

\footnotetext{
${ }^{3}$ Along with a detailed linear commentary on the contents and a series of chapters in which I have addressed some relevant points in the papyrus; the full translation of the Londiniensis into Italian will soon be available online at http://veprints.unica.it/.
}

${ }^{4}$ Nutton (1996), pp. 718-9; CPF Aristoteles 37T, p. 347. For a detailed review of these three sections see Ricciardetto (2016), pp. LI-CXIV.

${ }^{5}$ Cols. I, 1 - IV, 17. Ricciardetto (2016), pp. LI-LVIII. The first four columns have been studied separately by D. Manetti, who has also recently translated them into Italian; the same applies to T. Dorandi. Cfr. Manetti (2016), pp. 525-27; Dorandi (2016), pp. 199-205.

${ }^{6}$ Cols. IV, 18 - XXI, 8? Cfr. Ricciardetto (2016), pp. LVIII-XCVIII.

${ }^{7}$ Cfr. Ricciardetto (2014), p. XXXII; (2016), p. LIX. For an almost coeval medical view (fifth century BC) on the concept of 'cause' see Hippocrates Vet. med. XIX [I pp. 616, 17 - 618, 1 Li.].

${ }^{8}$ Abas?, Alcamenes of Abidos, Heracleodorus?, Niny? the Egyptian, Timotheus of Metapontum, Thrasymachus of Sardis, and Phasitas of Tenedos. Cfr. cols. VIII, 35 - IX, 4; VII, 40 VIII, 10; IX, 5 - 19; IX, 37 - X, ?; VIII, 11 - 34; XI, 42 - XII, 8; XII, 36 - XIII, 9 respectively.

${ }^{9}$ Cols. IV, 20 - XIV, 11.

${ }^{10}$ Cols. XIV, $12-$ XVIII, 8.

${ }^{11}$ Cols. XIV, $12-$ XXI, 8 ?

${ }^{12}$ Cols. XXI, 18 - XXXIX, 32. Cfr. Ricciardetto (2016), pp. XCVIII-CXIV. In the last section of the Anon. Lond., the body and its functions are studied by means of a juxtaposition of Herophilus's, Erasistratus's, Asclepiades', and Alexander Philalethes' views. Cfr. Nutton (1990), p. 247. 
Apart from this, on the verso of the papyrus there are three more writings, what turns the Anonymus Londiniensis into an opistographic papyrus. This feature alone does not make it unique; what makes the difference is the fact that the different kinds of writing on the verso of the Londiniensis belong to three different hands. The first of such opistographic writings consists of two notes that the scribe of the Londiniensis wrote on the verso in his aim to supplement the argument he was developing on the recto ${ }^{13}$. Second, the verso has also preserved the blurred and tiny traces of some words in a prescription. Third, the verso also bears the rescript of an edict of the emperor Marcus Antonius in which are collected the grants bestowed to a body of (crowned) winners in some kind of sacred games.

\section{The Thesis}

Now, having provided a succinct explanation about the main lines of the text under consideration, in what follows I will address the question whether an Aristotelian medical doxography, now lost, ever in fact existed. From this analysis will ensue the thesis that a part of the second section of the Londiniensis papyrus would have been mainly shaped according to an Aristotelian text, whereas the third section of the papyrus

${ }^{13}$ The first addition is a supplement to $11.46-47$ in col. XXV and was written behind cols. XXIII - XXIV. The second addition supplements $11.19-21$ in col. XXIV and was written behind cols. XXII - XXIII. Cfr. Ricciardetto (2016) pp. 185-6. The second major addition can be found in the translation into German but not in the English translation. Both additions were written on the same $\kappa o ́ \lambda \lambda \eta \mu \alpha$ where the medical prescription was penned. Ricciardetto (2016), p. CXIX n. 388. In his former edition of the Anonymus, and somewhat coinciding with

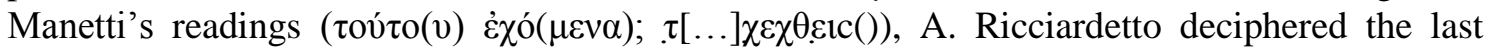

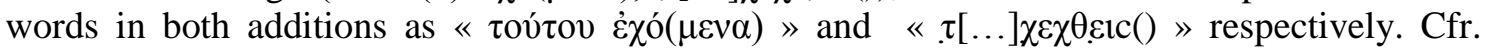
Manetti (2011), pp. 95-6 and Ricciardetto (2014), p. 38. On the $3^{\text {rd }}$ December 2015 A. Ricciardetto told me with enthusiasm about the new readings he found during his last autopsical examination of the papyrus in London. He was able to make a much better deciphering of the last word in the second addition, thus, he could make $\pi[\rho \circ c \varepsilon] v \varepsilon \chi \theta \varepsilon \underline{i c}(\alpha)$ from the initial $\tau[\ldots] \chi \varepsilon \chi \theta \varepsilon ı c()$ which unmistakably led him to reveal that the scribe had given a clear deictic, referential, or ostensive meaning to the word $\pi \rho \operatorname{coc}_{\varepsilon} \varepsilon \chi \theta \varepsilon i \tilde{c} \alpha$ in col. XXIV, 20. Ricciardetto (2016), p. 66. This new reading cast much more light upon the addition, for now the sentence took on the following sense: 'See inside (scil. of the papyrus) " $\pi \rho о \varepsilon \varepsilon v \varepsilon \chi \theta \varepsilon i \tilde{c} \alpha$ " '. After his realization Ricciardetto thought that perhaps the same could be applied to the first addition, and it

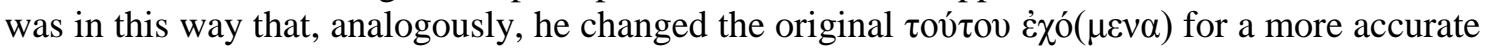

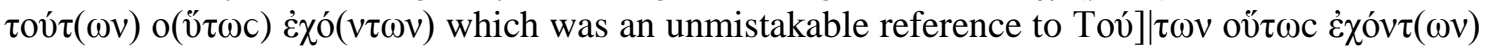

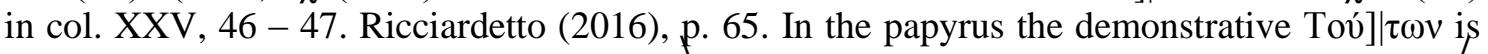

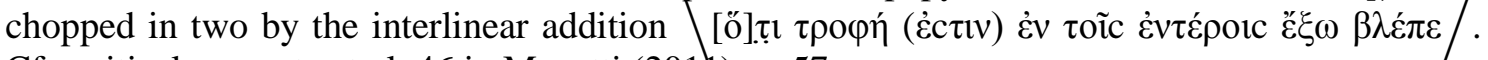
Cfr. critical apparatus to 1. 46 in Manetti (2011), p. 57. 
would have relied on a different source. I have found no explicit evidence that such a conjecture might have been formulated in these terms before.

\subsection{The Londiniensis, a Collage}

The Londiniensis is the result of a combination of different texts. The second section (and to some extent perhaps also the third) is doubtlessly drafted on manuals of ethics, medical definitions, different doxographies, exegetic material of diverse nature, collections of problems, collections of debates in utramque partem etc ${ }^{14}$. We could point to a series of indications corroborating this. In regard to Hippo of Croton ${ }^{15}$, for instance, in col. XI, 33 - 36 we read: (« but in another book the same writer says that the above-mentioned moisture changes $\gg)^{16}$. Likewise, a short while later in $11.42-43$ the scribe goes on by saying (« (scil. Hippo) does not indicate the diseases that result $\gg)^{17}$. Such complaint owes to the fact that, according to the rhetorical scheme that the author of the Londiniensis might have found for the previous authors, at this point he was expecting a description of different kinds of disease ${ }^{18}$, but he could find none; this means that the scribe tries to respect and to follow the same expositive order in the source which he is using. Along the same lines, in col. XIX, 18 - 20 we read: («

${ }^{14}$ Cfr. Manetti (1996), p. 295; (2013), p. 164.

${ }^{15}$ Diels (1893b), p. 420; Ricciardetto (2014), p. XL. A. Thivel affirms that this physician was also known as 'Hippo of Samos'. Thivel (2001), p. 203. The passage in the Londiniensis concerning Hippo of Croton was severally edited, translated into Italian, and commented on by D. Manetti in CPF Hippo Crotoniates 1T, pp. 456-7. The full and real name of the personage was Hipponax (I $I \pi \tilde{\omega} v \alpha \xi)$, but he will be known by means of the hypochoristic form "I $\pi \pi \omega v$. Diels (1893a), p. 115. It is from the Anon. Lond. papyrus that we come to know the medical theories of this author who previously had mainly been considered a philosopher. Originally from Samos, Hippon lived in South Italy, in Croton, and in Metapontus. In light of ancient textual witnesses, Hippon's impact among his contemporaries was rather little. He is derided in Cratinos's comedy titled Panoptai (a kind of ante litteram Aristophanes' Clouds), and his philosophy is defined by Aristotle as mediocre, and in fact Aristotle belittles him as a philosopher. Cfr. Aristotle Metaph. I 3, 984a 8 - 11; de An. I 2, 405b 2.

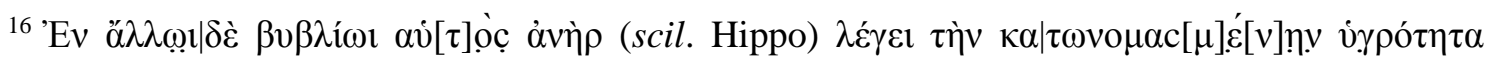
$\mu \varepsilon \tau \alpha \beta \alpha \dot{\alpha} \lambda \mid \lambda \varepsilon i v$. Transl. Jones (1947), p. 53.

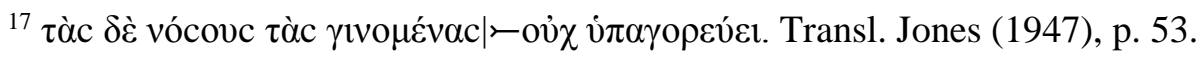

${ }^{18}$ Manetti (1990), p. 223 n. 13. The same observation can be found in col. XX, $14-16$ with regard to Petron of Aegina. 
Menecrates surnamed Zeus when setting forth in his book Medicine $\gg)^{19}$. Despite all these mentions of different works, from these hints it does not follow that the scribe necessarily read the books to which he makes reference.

\section{Aristotle and the Londiniensis Papyrus: Some Issues}

So far as the existence of an Aristotelian compilation is concerned, of a medical doxography which, as it seems, served as the basis for the redaction of the second section of the Londiniensis, I am not going to repeat the reasons pointing to an evident relationship between some treatises in the Corpus Hippocraticum and the works by Aristotle and the Aristotelians ${ }^{20}$. But, in brief, I should say that Aristotle and his disciples had access to a wide textual repertory of Hippocratic writings ${ }^{21}$. Thus, some statements that Aristotle presents as if they were of his own can be traced, in many cases, to extant ideas formulated in the Hippocratic collection ${ }^{22}$. Apart from this, it is well known that in the Classical period there was a particular literary genre in which medicine merged with philosophy and the dialectical method the most: the so-called discourses of thesis ${ }^{23}$.

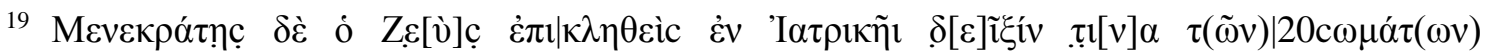

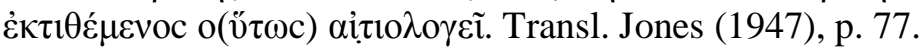

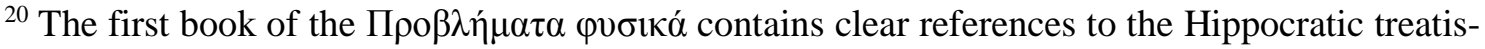
es Airs, Waters, Places and Aphorisms. Such textual interdependence was highlighted by the Italian physician L. Septalius in the beginning of the $17^{\text {th }}$ century, and later on by F. Poschenrieder and H. Diller. Poschenrieder (1887), pp. 43 - 53; Diller (1932), pp. 141-3. Cfr. Kudlien (1989), p. 360; Jouanna (1996), p. 275. In sum the issue is based on a sharp comparison between Hippocrates Aer. XI [II pp. 50, 17 - 52, 9 Li.] and Aph. III, 11 - 14 [IV pp. 490, 2 - 492, 6 Li.] and Pseudo - Aristotle Pr. I 8 - 12, 19, 20. Cfr. Jouanna (1996), pp. 273-4, 281-2. In respect to this comparative research, it is believed that Aer. X furnished the material for Aph. III, 11 - 14. Cfr. Roselli (1989), p. 184. The majority of scholars concerned with the Hippocratic tradition tends to ascribe Aphorisms and Airs, Waters, Places either to Hippocrates or to the members of a group settled on Cos that shared Hippocrates' ideas. Vegetti (1995b), pp. 45-6 n. 38. It is also remarkable in this sense that almost sixteen fragments in the Про $\beta \lambda \eta \mu \alpha \tau \alpha$ seem to depend in the final on a kindred cluster of books in the Epidemics (scil. Epid. II-V-VI). Cfr. Bertier (1989), pp. 261-2. All this yields definitive evidence of the fact that some writings attributed to Hippocrates were fairly known among the Peripatetics.

${ }^{21}$ Nat. hom.; Epid. II; Loc. Hom.; Morb. Sacr.; Morb. II; Epid. V and VII; Genit. - Nat. Puer. Morb. IV. Cfr. Longrigg (1995), p. 432; Van der Eijk (2014), pp. 351 n. 18, 366; Manetti (2014), pp. 234, 240.

${ }^{22}$ Joly (1968), p. 220.

${ }^{23}$ Along with Breaths and The Art, the treatise titled Ancient Medicine belongs to a well witnessed literary genre in the Corpus Hippocraticum known as 'discourses of thesis'. Ever since 
Independently of the fact that many ideas in Aristotle are possibly bound up with some books in the Hippocratic collection, I have to say that, though scarcer, we do have a few reports on a purported Aristotelian medical treatise - in two books - enti-

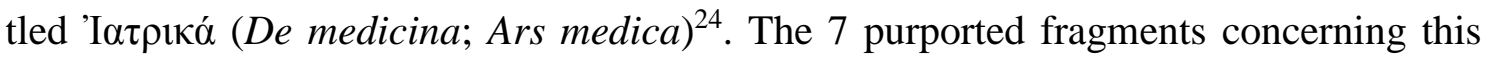
writing are severally collected in the former edition of the Anonymus Londiniensis pa-

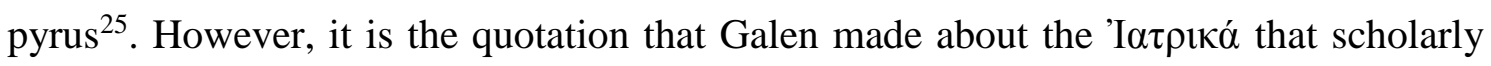
tradition will eventually assume. In his Commentary on Hippocrates' The Nature of $\operatorname{Man}^{26}$ Galen wrote: 'he who wishes to gain insight into this subject (scil. the causes of disease) should read the Medical Compendium ${ }^{27}$ which, although having been ascribed

Galen it is believed that the Ancient Medicine was not by Hippocrates. Jouanna (1992), p. 530; Jouanna (2012e), p. 149 n. 33. Beside the deliberative and the forensic, the epideictic was one of the main kinds of rhetorical speech. Aristotle Rh. I 2, 1358b; III 17, 1417b; EN VII 6, 1148b 27 - 34. Cfr. Pearcy (1993), pp. 446-8. Two epideictic speeches about medicine have been fully preserved, the treatises titled Breaths and The Art. They form part of a larger group of oral works (i.e. discourses) in the Hippocratic Corpus that were composed to be read or spoken out loud before an audience. Jouanna (2012c), pp. 40 n. 6, 41, 43 n. 13, 44.

${ }^{24}$ Diogenes Laertius Vitae philosophorum V 25 [Marcovich (1999), p. 324, 14]. Cfr. Diels (1893a), p. XVI; Moraux (1951), p. 25; Kudlien (1989), p. 358; Van der Eijk (1999), p. 493; $C P F$ Aristoteles 37T, p. 350. Abbreviations for the titles of Hippocratic and Galenic treatises are given according to: Fichtner, Gerhard. 2016. Corpus Hippocraticum. Bibliographie der hippokratischen und pseudohippokratischen Werke. Berlin: Berlin-Brandenburgischen Akademie der Wissenschaften. Available online at http://cmg.bbaw.de/ online-publikationen/HippokratesBibliographie_2016-12.pdf (accessed 22 February 2017); Fichtner, Gerhard. 2016. Corpus Galenicum. Bibliographie der galenischen und pseudogalenischen Werke. Berlin: Berlin - Brandenburgischen Akademie der Wissenschaften. Available online at http://cmg.bbaw.de/onlinepublikationen/Galen-Bibliographie_2016-12.pdf (accessed 22 February 2017). Abbreviations for Plato's dialogues and Aristotle's treatises have been respectively drawn from pages XXXIII and XIX (Epigraph I: Authors and Works) in Liddell, Henry George and R. Scott, Robert. 1996. A Greek - English Lexicon (with a Revised Supplement). Oxford: Clarendon Press.

${ }^{25}$ Diels (1893a), pp. 77-8. Also in its respective translations into German and English, since both Beckh - Spät and Jones take up Diels's edition. Cfr. Beckh - Spät (1896), pp. 68-70; Jones (1947), pp. 5-6. In this sense, I. Tacchini's contempt for the usefulness of Jones' edition is incorrect, for Jones' The Medical Writings of Anonymus Londiniensis is not an edition. Tacchini (1996), p. 711.

${ }^{26}$ Galen In Hipp. Nat. Hom. comment. I 1 (99) [XV pp. 25, 15 - 26, 2 K.] = I 2 (25/26) [CMG V

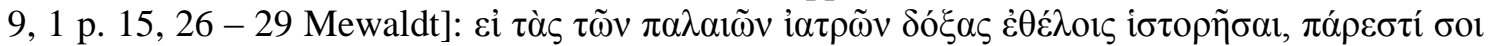

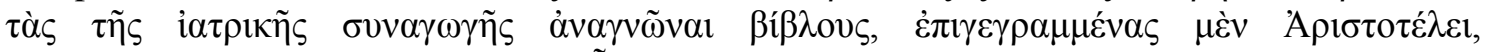

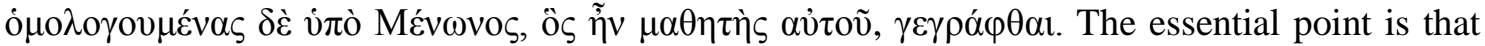
Meno is solely known by means of this Galenic quotation. Cfr. Withington (1929), p. 183; Gigon (1987), pp. 511-2 fr. 354; Manetti (1986), p. 61; (1990), p. 220; (1999), pp. 98-9; CPF Aristotle 37T, p. 348. Along with his commentary on Airs, Waters, Places, the linear commentary on The Nature of Man is the other Hippocratic commentary that Galen wrote by the end of his lifetime. Jouanna (2012f), p. 319.

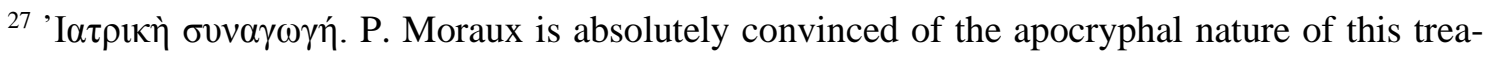
tise. Cfr. Moraux (1951), pp. 186-8. 


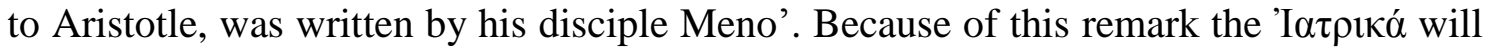
be also known as Menonia or Menoneia ${ }^{28}$. Galen's note matches well with the encyclo-

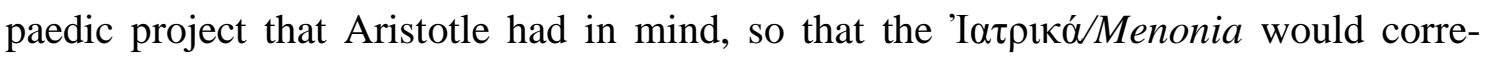
spond to the exhaustive investigation into the history of the different disciplines that Aristotle would have commended to some of his disciples, in the case of Meno in particular, that of the medical literature stored in the library of the Lyceum ${ }^{29}$.

From the moment of its discovery F. Kenyon launched the hypothesis that the

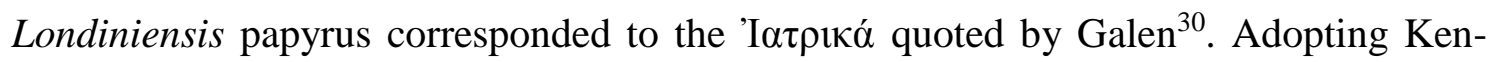
yon's standpoint, in $1893 \mathrm{H}$. Diels contended that the second section in the Anonymus Londiniensis papyrus ${ }^{31}$ was an epitome based on the Iatriká or Menonia ${ }^{32}$. I want to remind the reader that H. Diels's edition of the Anonymus bears the title Anonymi Londinensis ex Aristotelis Iatriciis Menoniis et aliis medicis Eclogae. It was so that, in relying on Galen, in the long run the hypothesis set out by Kenyon and Diels about the Aristotelian origin of the Anonymus would become dominant in the majority of studies on the London papyrus. Thus, the second section of the Anonymus Londiniensis was accepted as confirmatory evidence of the existence of a medical doxography that, under the label 'Aristotle', circulated in Egypt at the end of the first century $\mathrm{CE}^{33}$.

${ }^{28}$ Galen In Hipp. Nat. Hom. comment. I 1 [XV p. 26, 1 - 3 K.] = I 2 (26) [CMG V 9, 1 p. 15, 29 - 30 Mewaldt]. The existence of a work entitled $\tau \dot{\alpha}$ Mevóvela is witnessed in Plutarch Quaest.

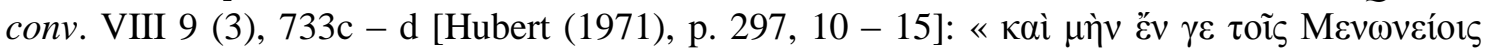

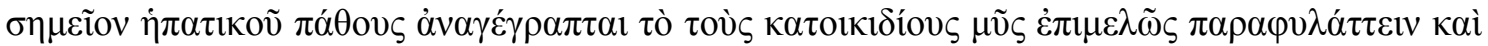
$\delta ı \omega \kappa \varepsilon \varepsilon v \cdot »$, ( What is more, in the works of Meno it is given as a sign of liver disease that a patient watches attentively for the mice of the household and pursues them »). Transl. Minar (1961), p. 199. Cfr. Rose (1863), p. 388 [T. 1.2 (331, 332)]; Diels (1893a), p. 77 fr. III; Beckh Spät (1896), pp. 68-9; Jones (1947), p. 5; Gigon (1987), p. 511 fr. 353. The existence of such Menonia is in fact taken for granted in the title of the editio princeps by H. Diels ( ex Aristotelis Iatriciis Menoniis »), as well as in the Realenzyklopädie. Cfr. Raeder (1931), p. 927. CPF Aristotle 37T, pp. 348-9; Kudlien (1989), pp. 358-9; Jouanna (1992), pp. 90, 376; Squillace (2013), p. 173. There is a trend of specialists, P. Moraux among them, who equates the Prob-

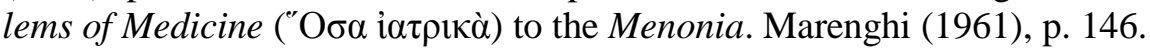

${ }^{29}$ Rose (1863), p. 385. So far as this subject is concerned, it is known that Theophrastus - Aristotle's successor as head at the Lyceum - wrote short tracts on medical topics as sweating, fatigue and giddiness. Galen De san. tuenda. III 5 [VI p. 190, 4 - 5 K.]. Cfr. Bertier (1989), p. 261; Nutton (2004), p. 120.

${ }^{30}$ Kenyon (1892), pp. 237-40; Diels (1893b), p. 407; CPF Aristoteles 37T, p. 348.

${ }^{31}$ I.e. cols. IV, 18 - XXI, 8?

${ }^{32}$ Cfr. Manetti (1990), pp. 220; (1999), p. 98.

${ }^{33}$ Van der Eijk (1995), p. 452 n. 20. 
Yet, to start with the counterarguments, part of the issue is that it is not clear at all who Meno was. D. Manetti maintains that in the first two centuries CE about as much was known about Meno as we do today, which amounts to saying that it cannot be said for sure that Meno ever existed ${ }^{34}$. In any event, according to Manetti, it cannot be discounted that the papyrus might represent an Aristotelian lost work to which the scribe of the Anonymus had direct access ${ }^{35}$. Were it true, the second section of the Anonymus papyrus would be a jumble of quotations, meditations, and comments drawn on the treatise titled On Health and Disease for which Aristotle is given credit.

Not only do the shadows on Meno's factual identity shed uncertainty upon the subject, but the title given to the papyrus is problematic too. Since not even a minimal trace of ink on the papyrus support is to be found where Manetti's edition of the Londiniensis indicates the presence of the term 'I $\alpha \tau \rho \iota \kappa \alpha$ ', which, in a way, would confirm the hypothesis launched by Kenyon and Diels; by heading the first page in her edition ${ }^{36}$ with the word 'IATPIKA' Manetti's title is automatically called into question. Manetti's addition is troublesome from a papyrological point of view ${ }^{37}$, for, according to the standard conventions of the papyrological discipline, in finding the supposed title in angular brackets (i.e. 〈IATPIKA〉) $)^{38}$ the reader is asked to assume that 'IATPIKA' was a word omitted by the scribe ${ }^{39}$, and on the other hand, that 'IATPIKA' is also the title of the whole papyrus which, if not wrong, is even more debatable. Both the actual state and the nature of the papyrus suggest that the scribe could not have wanted to give it a title at all, or at least, not the title that Manetti proposes.

Leaving these two preliminary problems aside, my purpose for the moment is to illustrate how the handling of the papyrus is in accordance with the existence of several prographa, and more particularly, with the existence of an Aristotelian medical source

\footnotetext{
${ }^{34}$ Manetti (1990), p. 220; (1999), pp. 98-9; Ricciardetto (2016), p. XLVII. H. Diels already went over Meno's identity. Diels (1893b), p. 409.

${ }^{35}$ Manetti (1986), pp. 59-64; (1990), p. 222; (1994), pp. 57-8. Cfr. Gigon (1987), p. 511; Van der Eijk (2005), p. 264.

${ }^{36}$ Manetti (2011).

${ }^{37}$ Ricciardetto (2014), p. 41.

${ }^{38}$ Manetti (2011), p. 1. Moreover, the supposed title is wrongly transliterated all through the edition: IATPICA. Cfr. Manetti (2011), p. 3 passim every odd number page. Ricciardetto (2016), p. 70.

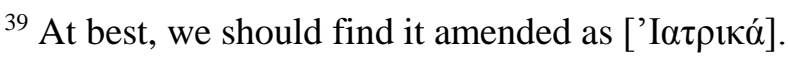


(whehter by Aristotle himself or by his disciple Meno) on which the scribe of the Londiniensis fixed his gaze when he was writing the papyrus.

\section{1 The Aristotelian Ground}

Matters take a different turn in relation to the supposed Aristotelian source, for not only does the papyrus allude to Aristotle several times ${ }^{40}$, but above all because in col. VII, 41 - 43 the scribe wrote: 'Alcamenes of Abydos, according to the account of him given by Aristotle, says that diseases occur through' ${ }^{41}$. In the same vein, it is assumed that the subject of the verb $\varphi(\eta$ cív $)$ in col. XII, 8 is Aristotle, an assumption that

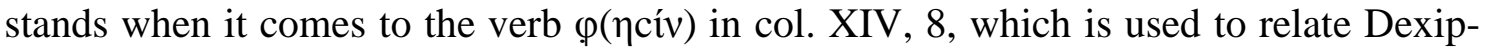
pus's theory of the causation of disease. Therefore, these subtle hints that the scribe drops contain the key to infer that the report on the authors comprised between cols. VII, 43 - XIV, 8 lies in a source ascribable to Aristotle.

But a more patent witness of the existence of such Aristotelian source comes to the fore from the content of cols. V, 35 - VII, $40^{42}$. Concretely, in cols. VI, $42-44$ and VII, 37 - 40 the scribe insists on the fact that a distinction must be drawn between what Aristotle believed that Hippocrates had to say on the matter, and what Hippocrates really hypothesised on the causes of disease. In the Anon. Lond. such distinction is stressed

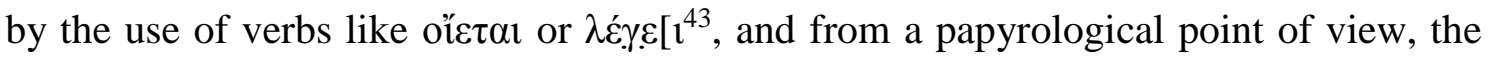
contrast in the opinions is also stressed by the presence of a diple obelismene between 11. $43-44^{44}$. Here we bump into a theory that looks to be in conflict with everything that, in general, we have been told and taught about Hippocrates ${ }^{45}$. The author of Anon.

${ }^{40}$ In the Anonymus Londiniensis Meno would be called 'Aristotle'. Cfr. supra n. 28. In the Anonymus the name 'Aristotle' occurs in cols. V, 37; VI, 42; VII, [38], 43; XXIII, <42>; XXIV, 6. Cfr. cols. VII, [38] - 40, 42 - 43; VIII, $10-12$.

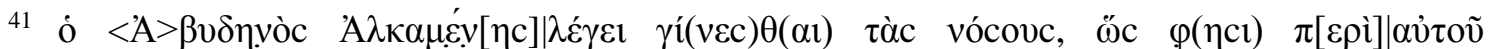

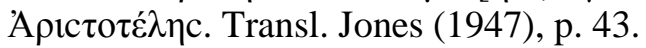

${ }^{42}$ Cfr. Jones (1984), p. XL.

${ }^{43}$ Cols. VI, 42 and VII, 38 respectively. Cfr. Kudlien (1989), p. 358; Nutton (2004), p. 207.

${ }^{44}$ The Anonymus papyrus does not present any other kind of punctuation mark apart from the paragraphos «__ » and the diple obelismene « $\succ$ » (or forked paragraphos). By both signs the scribe intended a clear and plain pause (a trait that sometimes is also stressed by a spatium vacuum), or else a passage from the opinions of a particular author to another. Manetti (2013), pp. 161-2, 175; Ricciardetto (2014), p. XXIII. 
Lond. argues in fact that, if we were to believe Aristotle, Hippocrates should be considered as a physician partaking in the views of those who ascribed the causation of disease to the residues; yet, in his eyes, the version that Aristotle offers of Hippocrates is incorrect. This is actually the intended meaning of col. VI, $43-44$, where the scribe remarks: 'But what Hippocrates himself says is that diseases are caused by...'46.

\section{2 Another Hint from an Aristotelian Perspective}

Moreover, and following the opinion of the majority of experts on this issue $e^{47}$, my primary point is that in cols. VI, $45-$ VII, 1 the scribe brings into discussion the Hippocratic treatise The Nature of $\mathrm{Man}^{48}$, as it is to this work that he deems that one should go to read Hippocrates' real opinions about the causes of disease. As a matter of fact, it is in The Nature of Man where the contrast between the two categories of disease and the two types of causes to which the Londiniensis makes reference is asserted with the greatest clarity ${ }^{49}$. The alternative put forward by the scribe tallies much better with the Hippocratic humoral theory to which we are accustomed ${ }^{50}$. That would do were it not for the fact that the objection raised by the scribe introduces three non-trivial mat-

${ }^{45}$ According to D. Manetti there is nothing in the Anon. Lond. suggesting that the scribe would have held radical doctrinal differences in respect of Hippocrates. Manetti (1999), p. 310. Such interpretation is in conflict with J. Jouanna, who actually contends that the author of Anon. Lond. manifests a clear-cut anti-Hippocratic view.

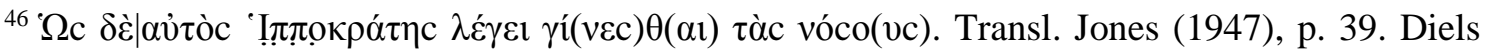
(1893b), p. 430. This short passage was translated into Italian by D. Manetti in CPF Aristoteles 37T, p. 346, later on in more detail in Manetti (1996), pp. 296-7. Though giving an inconsistent quotation, the general intendment of the passage is recollected in Vegetti (1995b), p. 94 n. 23.

${ }^{47}$ W. H. S. Jones, the translator of Nature of Man into English, remarks that the Anonymus quotes (or rather paraphrases) Nat. hom. IX. Jones (1979), p. 25 n. 1.

${ }^{48}$ As it seems, Hippocrates Nat. hom. IX [VI pp. 52, $11-56,12$ Li.]. The disagreement is grounded in the intermingling of both passages with some other content that the scribe apparently drew from Hippocrates Morb. I.

${ }^{49}$ Jouanna (2012d), p. 127. As a matter of fact, in his translation of The Nature of Man W. H. S. Jones remarks that the Anonymus quotes, or rather paraphrases, Nat. hom. IX. Cfr. Jones (1979), p. 25 n. 1. For a less restrictive typology of causation of disease in the Hippocratic collection see Hum. XII [V p. 492, 7 - 10 Li.].

${ }^{50}$ Or the so-called 'Hippocratic vulgata of the Imperial period' as we see it expounded, for example, in Hippocrates Nat. hom. IV [VI pp. 38, 19 - 40, 2 Li.]; V [VI p. 40, 15 - 16 Li.]. Cfr. Jones (1984), pp. XLVIII - XLIX; Manetti (1996), p. 296. In any case, either the predominance of one humour upon the rest or their uneven mixture are likely to engender harmful gases. Steckerl (1945), p. 177. 
ters. The first one lies in the conjectural reading of the papyrus at this point ${ }^{51}$, so that in view of the lacunary nature of the papyrus we can only guess that the scribe is presumably alluding to the title of the Hippocratic treatise The Nature of Man. In the second place, it is rather strange that the author gives at this point a specific title of a work while, in fact, he does not mention the name of the second treatise which, it seems from the content, is also purportedly alluded to (i.e. Diseases) ${ }^{52}$. The third difficulty lies in the scribe's apparent unawareness of the fact that Hippocrates might not have written The Nature of Man; for, to the Aristotelians ${ }^{53}$ it was Polybus of $\operatorname{Cos}^{54}$ (Hippocrates' disciple and son-in-law) who was credited with doing so.

I should like to make a brief aside and to centre my argument on this last question, since it is a first-rate example of the value of the Londiniensis papyrus as a source for the History of Ideas and the History of Medicine. Putting to one side Polybus of Cos, none of the physicians mentioned in the Anon. Lond. did actually reduce the fundamental elements in the human body to the straight four humours pattern of classical

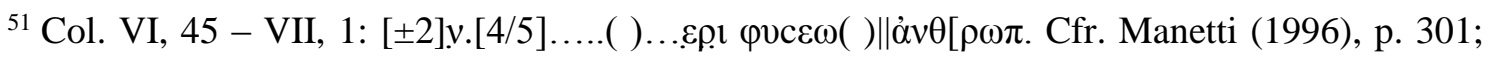
Ricciardetto (2014), pp. 49-50; (2016), p. 9.

${ }^{52}$ Hippocrates Morb. I 2 [VI p. 142, 13 - 20 Li.]. D. Manetti affirms that 11.3 - 15 are actually mirroring the Hippocratic treatise Diseases I. Accordingly, there have been attempts of recon-

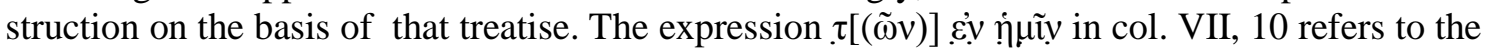

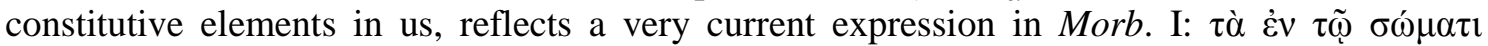

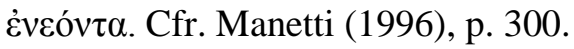

${ }^{53}$ Jouanna (1992), p. 94. Like Galen eventually will also do, the scribe of Anon. Lond. considers that the book The Nature of Man was written by Hippocrates. Galen does not care much about the attribution of the treatise to Polybus, since he thinks that master and disciple agreed in the fundamental. Galen is much more concerned with certain people who did not attribute The $\mathrm{Na}$ ture of Man to Hippocrates. Jouanna (2012f), pp. 317, 319-24.

${ }^{54}$ Diels (1893b), p. 430; Giannantoni (1984), p. 49; Manetti (1986), p. 63 n. 26; Jouanna (1988), p. 19; Vegetti (1995b), p. 93; Thivel (2001), p. 207; Nutton (2004), pp. 59-60; Byl (2011a), p. 242; (2011b), p. 93; Jouanna (2012g), pp. 335, 338; Manetti (2014), p. 233 n. 12; Ricciardetto (2016), pp. LXXI n. 20, XCIII - XCIV. Jouanna (1992), p. 552: 'C'est le seul traité de la Collection que l'on puisse attribuer à un auteur nommément connu, Polybe, disciple d'Hippocrate, si l'on admet l'unité de l'ensemble [...] Galien, qui a commenté le traité, attribue sa première partie contenant la théorie des quattre humeurs à Hippocrate'. Polybus's opinions are expounded in col. XIX, $2-18$. At HA III 3, 512b 12 - 513a 7 Aristotle gives a detailed description of the blood vessels, and for that he quotes extensively the middle part of Polybus's? The Nature of Man. Cfr. Diels (1893b), p. 430 n. 2; Blass (1901), p. 409; Jouanna (1993), pp. 23, 49; (2012f), pp. 315 n. 3, 320-3; Ricciardetto (2014), p. XLIV n. 278; Van der Eijk (2014), pp. 348-9. Aristotle and his heirs, who were in a far better position to know the truth than we are, believed that Hippocrates was not the author of the treatise The Nature of Man and gave credit for it to Polybus. Even when it had later become firmly associated with Hippocrates, Sabinus and Galen himself believed that parts of it were written by another and far more fallible author. 
Hippocratic theory ${ }^{55}$. It is precisely in the light of the report on Polybus's theory that Londiniensis comes in and seems to play a key role in the forgery of this issue. In col. XIX, $8-11$ the scribe wrote: 'In the second place, [Polybus] says that the mixing [that constitutes] the bodies is made from blood, phlegm, yellow bile and black bile ${ }^{56}$. The Anonymus papyrus reveals at this point a medical compilation of plain Aristotelian orientation in which the oft-known theory of four humours - the same theory we see expounded in the first section of The Nature of Man (chaps. III-IV) - is not assigned to Hippocrates but ascribed to one of his students and relatives ${ }^{57}$. I would remind the reader that I am arguing for the likelihood of an Aristotelian medical doxography at the basis of the Londiniensis papyrus. In this sense, it is also worth stressing that in the History of Animals ${ }^{58}$ Aristotle assigns to Polybus the long description of the blood vessels that we see in chapters IX - XV in The Nature of Man. So far, thus, Aristotle (and the Aristotelians) took the description of the blood vessels in the second section in The $\mathrm{Na}$ ture of Man as written by Polybus.

To bring back the concern to our present interest, as regards the first objection ( that is, whether the papyrus transmits the title 'The Nature of Man' or not), I should say that in the event that the title 'The Nature of Man' were literally quoted, it would bely what looks to be dominant all through the Londiniensis: the omission of the title of the sources on which the author dwells. Yet, insight into the content immediately

${ }^{55}$ Menecrates (cols. XIX, $18-\mathrm{XX}, 1$ ) also argues that the body is created from four elements, two hot (blood and bile) and two cold (breath or pneuma and phlegm). Along with Polybus, Menecrates is the only physician reviewed in the second subsection of the second section of the Anonymus papyrus of whom, in a narrow sense, the scribe clearly states that put the cause of disease to the elements in us.

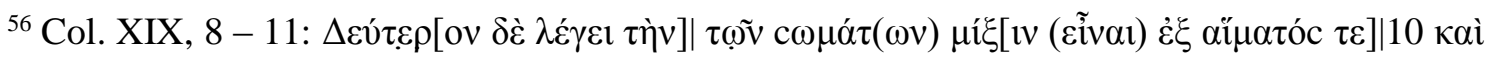

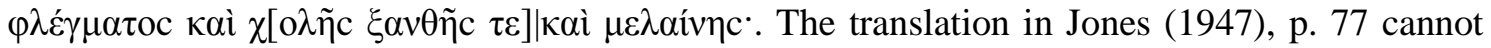
help this time because the Greek text has been modified since Diels's edition (on which Jones' translation is based). The integration '[that constitutes]' is in connection with the infinitive $\gamma \varepsilon v v a \tilde{c} \theta \alpha \mathrm{r}$ in col. XIX, 3 which still rules (and is understood) over the translated sentence in question.

${ }^{57}$ We should add, moreover, that it was Galen who gave the theory of the four humours its prestige by showing in his Commentary on Hippocrates' The Nature of Man that this theory was the foundation of Hippocrates' work. In omitting the crucial witness of Aristotle concerning the blood vessels, Galen made an incredible blunder of judgement by attributing to the master what was the work of one of his pupils. Jouanna (2012g), p. 338. The testimony of the Anonymus Londiniensis undermines Galen's struggle for smoothing the different authorship that he gives to The Nature of Man; in the light of the report on Polybus in the Londiniensis the entire fiction of Galen on the genesis of The Nature of Man might perfectly crumble.

${ }^{58}$ Aristotle HA III 3, 512b 12 - 513a 7. 
following ${ }^{59}$ in the Londiniensis points to a factual reference to Polybus's The Nature of Man. Even though the scribe maintains that it is an explanation that does not really match the facts, he claims that, besides an excessive cooling or heating of the bile or the phlegm $^{60}$, Hippocrates advanced two other possible causes for disease: air (ảmò $\tau$ õ

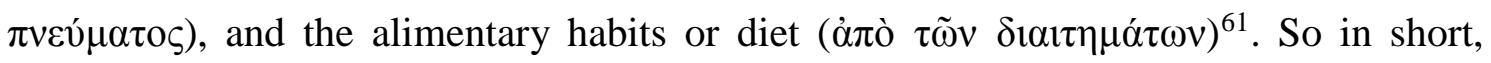
general diseases originate from the miasmas contained in the air, and individual diseases originate from dietary regimen - a distinction which is made in two Hippocratic treatises, in Breaths ${ }^{62}$ and in The Nature of Man $^{63}$. By the former cause, airborne miasmas, is meant the agent that acts upon a population when many people are suddenly

${ }^{59}$ Col. VII, $18-21$.

${ }^{60}$ It should be kept in mind, moreover, that the quaternary humoral scheme (blood, phlegm, black bile, and yellow bile) as we see expounded in Hippocrates Nat. hom. IV-V is, as such, unattested in the majority of books of the Hippocratic collection. Anon. Lond. makes mention of only three humours (phlegm, bile, and blood); so that, on grounds of this detail, at this point in the argument the author of the Anonymus could not have been paraphrasing Hippocrates' (Polybus's) The Nature of Man. We should remember that Philolaos of Croton only conceded the existence of those same three humours, and as has been said, it is likely that he found this theory in the philosophy of the pre-Socratic sophist Prodicus, who is credited with having written a

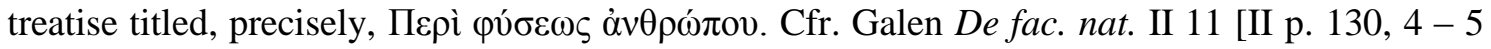
K.]; Diels (1893b), p. 419 n. 1; Manetti (1990), p. 230; and cols. XVIII, 8 - XIX, 1. The only argument to which we could resort to claim that it is not the case seems to lie in the division established by the scribe himself, inasmuch as Philolaos (Prodicus) belongs to the second group of authors reviewed in the doxographical section; but, at any rate, Hippocrates' theory of causation of disease appears to be also a meddling in the logical order of the arguments that the scribe proposes.

${ }^{61}$ Hippocrates Nat. hom. IX [VI p. 52, 11 - 13 Li.]; [VI p. 54, 1 - 4 Li.]. Jouanna (2012e), p. 143 n. 20. At Nat. hom. IX [VI p. 54, 19 Li.] the air, in its morbific attribution, is termed ô

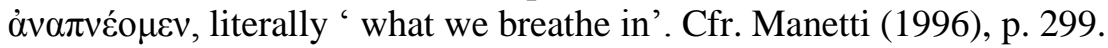

${ }^{62}$ The author of Breaths, a treatise that Aristotle/Meno took as a genuine work by Hippocrates, supposes that all diseases are caused by the air, so that he pictures the pneuma as the principal source of illness, this probably being why the scribe might have made use of that treatise in the etiological section. Hippocrates Flat. V [VI p. 96, 12 - 19 Li.] = [CMG I 1 p. 94, $1-7$ Heiberg]. Jouanna (2012d), p. 125; Van der Eijk (2014), pp. 363-4. Both the description of Hippocrates' etiological theory according to Aristotle (col. V, 35 - 37) and the pathological interpretation of pneuma in the Hippocratic treatise Breaths convey the same assumption, that is, massive intake of food in combination with lack of physical exercise, and the intake of too varied kinds of food may both lead to improper digestion. Food in excess brings about an excess of air in the body, be it due to the air inhaled at the same time as eating, or to some extra air that arises from the residues of the undigested food which is eventually added to the extant air in the body. The combination of these two facts is said to block the upper stomach. This blockage generates air bubbles ( $\varphi \tilde{v} c \alpha$ ) that cool down the parts of the body where sanguineous irrigation is major; thereby the whole body becomes excessively cooled, and with it the majority of natural functions become prevented or impeded.

${ }^{63}$ Jouanna (2012d), pp. 126-7. 
and almost at the same time gripped by the same illness. In the Corpus Hippocraticum

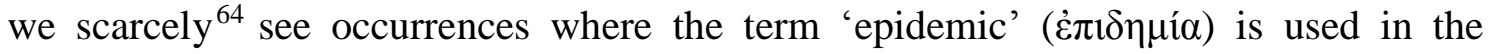
medical sense we nowadays attribute to it ${ }^{65}$ (that is, 'pestilence') ${ }^{66}$, or where reference is made to the majority of the population suddenly coming down with the same illness at once (which is also the intended meaning below in col. VII, 18-21). Yet it is precisely this scenario that we find in The Nature of $\mathrm{Man}^{67}$. In the circumstances, it could be by that token that this writing, which the Peripatetics attributed to Polybus and which was eventually ascribed to Hippocrates, was the treatise taken into consideration in the Anonymus papyrus. I should add that the objection that the scribe raises against this general Hippocratic theory seems here to be in agreement with the content of The Nature of Man itself ${ }^{68}$.

${ }^{64}$ Another similar use can be found in Hippocrates Progn. XXV [II p. 188, 12 - 14 Li].

${ }^{65}$ By $\dot{\varepsilon} \pi \_\eta \mu i_{\alpha} \alpha$ it was generally meant 'visit, notes taken by a physician while sojourning, sporadical arrival to a certain place, general affection coming about in one place at the same time, pestilence' etc. Cfr. Jouanna - Grmek (2000), p. 230 n. 6; Pino - Hernández (2008), pp. 200-1; Jouanna (2012d), p. 124.

${ }^{66}$ The view in which air is deemed a morbific agent is likely to do with the arrival of Plasmodium falciparum (fifth century BC) in the core of populations that had never been exposed to the parasite of malaria. The Hippocratic assumption whereby air was a morbific agent had terrible consequences because it prevented the necessity of seeking other possible causes beside, namely, human contagion. In the Hippocratic Corpus, contagion is not regarded as possible cause of disease; pestilence or epidemic diseases are attributed to respiration of morbific miasmas carried

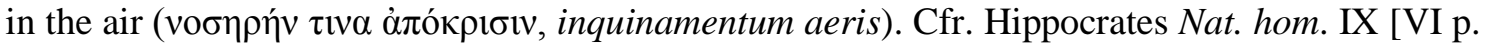
52, 14 - 17 Li.]; Flat. VI [VI p. 98, 2 - 13 Li.] = [CMG I 1 p. 94, $10-22$ Heiberg]. Cfr. Nutton (1989), p. 436; Jouanna - Grmek (2000), pp. VII - VIII; Jouanna (2012d), pp. 124-6; Van der Eijk (2014), p. 361. For an Aristotelian consideration of pestilence see Pseudo - Aristotle Pr. I $7,859 \mathrm{~b}$. As theoretical possibility, contagion was discarded among human, but it was pointed by vets in relation to what they observed in horses and cattle. Gourevitch (1995), pp. 427-9. However, by means of the participle $\alpha v \alpha \pi \mu \pi \lambda \alpha \dot{\alpha} \mu v v o$ Thucydides might well be making allusion to contagion when he describes the pest of Athens (430 BC) in the History of the Peloponnesian War II 51 (4/5) [Boheme (1896), p. 122, 5]. Cfr. Alsina (1989), pp. 215, 219; Byl (2011b), pp. 89-91; Jouanna (2012b), pp. 31-2 n. 21; (2012d), p. 135 n. 24.

${ }^{67}$ Cfr. Laín Entralgo (1982), p. 226; Jouanna - Grmek (2000), p. VIII n. 3, 230 n. 6.

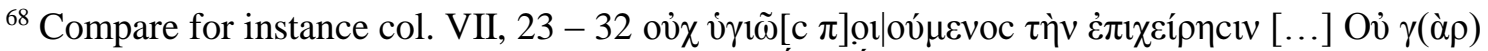

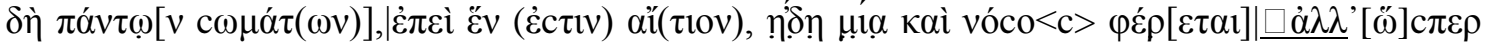

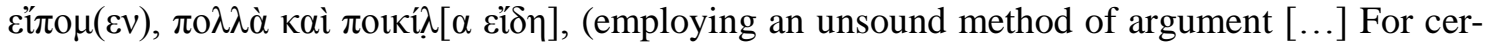
tainly one and the same cause does not bring one and the same disease to everybody, but, as we have said, many and various forms) to Hippocrates Nat. hom. IX [VI pp. 52, $17-54,4 \mathrm{Li}$.]:

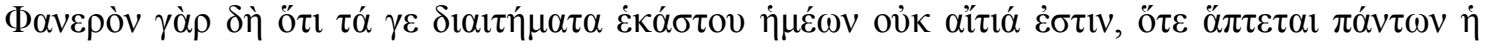

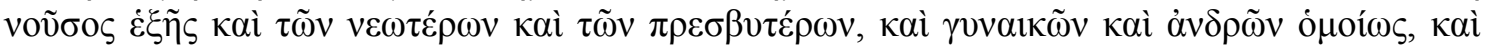

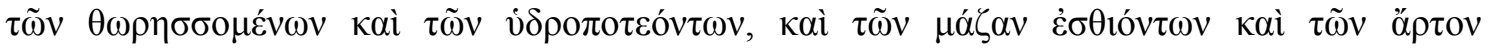

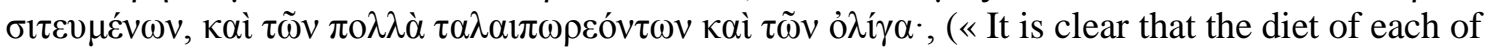
us cannot be the cause of disease, since it attacks everyone in turn, young and old, women and men and, without distinction, those who drink wine and those who drink water, those who eat 


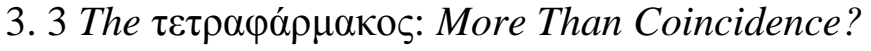

A further example that I should like to pick out as evidence that the Londiniensis papyrus is strongly imbued with an Aristotelian doxography is that to make clearer what the oúvұlois consists of, in col. XIV, 16 - 20 the author of the papyrus uses the $\tau \varepsilon \tau \rho \alpha \varphi \alpha ́ \rho \mu \alpha \kappa о \varsigma^{69}$ as an example to explain one of the possible types of combination between two or more substances; more particularly, the dissolution or contemporary fusion of some elements into a new one. Rather than it being a simple coincidence, the fact that Alexander of Aphrodisias ${ }^{70}$ uses the same example to describe this kind of phenomenon $(\sigma \dot{v} v \tau \eta \xi 1 \zeta)$ could give us another clue about the existence and the circulation of an Aristotelian doxographical source to which the scribe of the Londiniensis and Alexander of Aphrodisias still had access ${ }^{71}$.

\section{4 Some Lexical Notes}

So far as the use of an Aristotelian writing is concerned, from now onwards I should like to draw attention to the terminology that we see in the Anon. Lond. There is cogent proof for asserting beyond doubt that some terminological features in the papyrus are rooted in Aristotle's philosophy. Some good examples accounting for this are the privative adjective $\ddot{\alpha} \pi \eta\left[\kappa \tau o c^{72}\right.$; the verb $\dot{\alpha} v \alpha \theta v \mu 1 \alpha \theta \varepsilon \tilde{c} c \alpha{ }^{73}$, and the notions of

barley bread and those who eat wheat bread, those who do a lot of exercise and those who do little »). Transl. Jones (1947), p. 43 and Jouanna (2012e), p. 143 n. 20.

${ }^{69}$ Col. XIV, 19 - 20. Galen De const. art. med. I 6 [I p. 242, 5 - 8 K.]. Cfr. CPF Plato 129T, p. 555 . The $\tau \varepsilon \tau \rho \alpha \varphi \alpha ́ \rho \mu \alpha \kappa o \zeta$ was the plaster $(\chi \alpha \lambda \beta \alpha ́ v)$ par excellence in the past, and it was specially prescribed to cure open sores in the extremities. It was prepared by mixing an equal proportion of wax, tar, resin, and bull or calf fat. Galen Simpl. XI 2 [XII p. 328, 8 - 12 K.]; Celsus De medicina V 19, 9 [Daremberg (1891), p. 173, 28 - 31]. Cfr. Guardasole (1997), p. 102; Andorlini (2006), p. 158. Due to the texture resulting from the mixture of these four ingredients, the $\tau \varepsilon \tau \rho \alpha \varphi \alpha ́ \rho \mu \alpha \kappa o \zeta$ was considered a hard/compact ( $\sigma \kappa \lambda \eta \rho o ́ \varsigma)$ variety of plaster.

${ }^{70}$ Alexander of Aphrodisias De mixtione III (595) [Bruns (1892), p. 216, 23 - 25].

${ }^{71}$ As regards the possibility that such Aristotelian textual source was the treatise On Health and Disease, we should consider the caveat by Alexander of Aphrodisias in the In librum de sensu

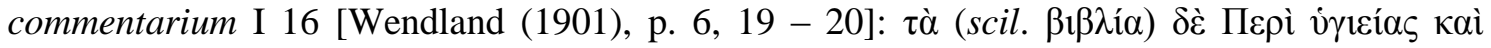

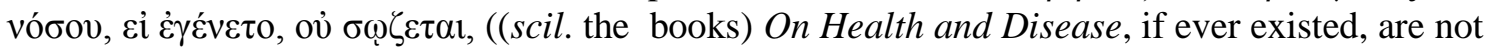
preserved). Heitz (1865), p. 58; Lloyd (2003), p. 176; Van der Eijk (1999), p. 493; (2005), p. 263.

${ }^{72}$ Col. XVII, [31]. Cfr. Liddell - Scott (2006), p. 188. 


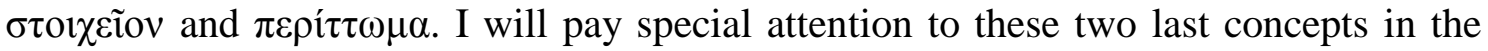
light of the stated purpose above.

In col. XX, $25-26$, where the scribe deals with Philistion's theory of causation of disease ${ }^{74}$, the author of Anon. Lond. wrote: 'Philistion thinks that we are composed of four "forms", that is, of four elements fire, air, water, earth. ${ }^{, 75}$. We should note the

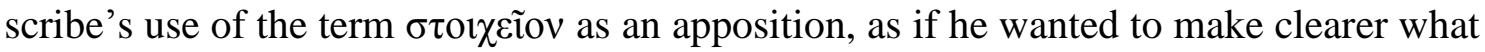
should be understood by the term i $\delta \varepsilon \tilde{\omega} v$. Out of caution, I will avoid saying that

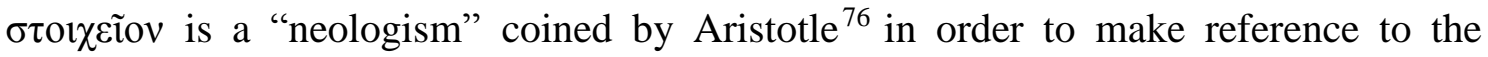
ontological principles of reality, and therefore also of the human body. Though such meaning is never attested in the Corpus Hippocraticum ${ }^{77}$, we do have a few fragments

${ }^{73}$ Col. VI, 32.

${ }^{74}$ E.g. Plato Ti. 86a. Plato knew about Philistion's theories during his first sojourn on Sicily (388 BC). Cfr. Galen Meth. med. I 1 [X pp. 5, 15 - 6, 8 K.]; Vegetti (1995b), p. 49. Prescinding from the problems concerning the authenticity of Plato's epistles, Philistion is cited in Ep. II $314 \mathrm{e}$. It is in general believed that Plato wrote the second epistle in the meantime of his second and third journeys to Sicily $(367-363 \mathrm{BC})$, precisely when it is agreed that he composed the Timaeus (the book in which Plato supposedly reassumes all what he could have learned with Philistion). Bidez - Leboucq (1944), pp. 7, 17-8; Abel (1957), p. 116; Nutton (2004), p. 115. For Philistion's influence on Plato see Schuhl (1960), p. 74; Miller (1962), p. 176 n. 6; Lloyd (1968), p. 79; Jones (1984), p. XLIX; Vegetti (1995b), pp. XIII, XX, 15; Ricciardetto (2016), p. XCVIII.

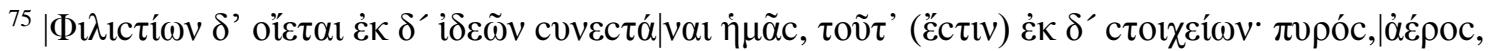

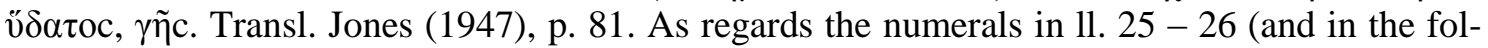
lowing), the way the scribe writes them is by adding a transversal stroke above; then, for example, the number 4 is not written as $\delta^{\prime}$ but as $\delta^{-}$. The same applies to 1.38 in the same column and to cols. XXI, 10; XXII, 54; XXVI, 49; XXVIII, 17, 23, 33, 49; XXIX, 17; XXXI, 33, 47; XXXIII, 3; XXXIII, 3; XXXVIII, 58 etc.

${ }^{76}$ Only in the Metaphysics the term is used more than 165 times Cfr. Delatte - Rutten - Govaerts - Denooz (1984), pp. 422-3.

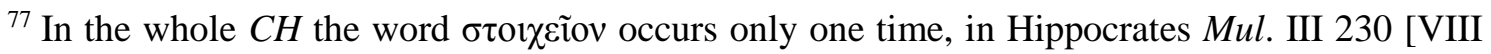
p. 444, 4 - 5 Li.]: $\sigma \tau o \imath \chi \varepsilon i \alpha ~ \delta \varepsilon ́ ~ \sigma o \imath ~ \tau \alpha \tilde{\tau \alpha ́ ~ \varepsilon ̇ \sigma \tau \imath v . ~ C f r . ~ K u ̈ h n ~-~ F l e i s c h e r ~-~ A l p e r s ~(1989), ~ p . ~ 749 . ~ I n ~}$ De mulierum affectibus III the term called into question does not have any ontological or stoichiological signification at all, rather it takes on the meaning of "means, tools, remedies, cures at hand" (scil. to treat barrenness due to the neck of the uterus is either harshened or too oblique so as to allow conception). The content in book De mulierum affectibus III (also known as De sterilitate) is said to be akin to the Coan school, and it is believed that was written by an independent author. Jouanna (1992), pp. 547-8. In the majority of treatises comprised in the Hippocratic collection what Aristotle would describe as $\sigma \tau$ ol $\chi \varepsilon i \alpha$ is called by means of other concepts

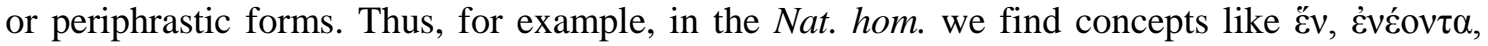

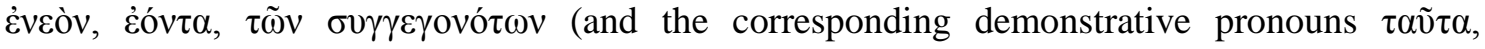

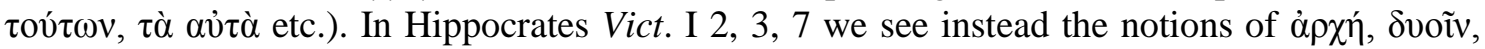
$\mu \varepsilon ́ p \eta$, [VI pp. 468, 8 - 9; 472, 13; 480, 11 Li.]. In Vict. I 28 the author makes reference to the generative material by the term $\tau \dot{\alpha} \sigma \omega ́ \mu \alpha \tau \alpha$ [VI p. 502, 5 Li.]. In Hum. 1 [V p. 476, 1 Li.] the words used are $\chi v \mu o v ̀ \varsigma, ~ \chi v \mu \tilde{\omega} v$, etc. 
from the pre-Socratics in which the word $\sigma \tau 0$ $\chi \varepsilon i \tilde{\alpha}$ refers to the principles of which the first physiologists deemed that the world was constituted, and as a matter of fact, the word $\sigma \tau 0 \imath \chi \varepsilon i ̃ \alpha$ in the sense of 'constitutive element' can be found in the Timaeus ${ }^{78}$ and in other dialogues by Plato ${ }^{79}$.

I have no special interest in averring that the content transmitted in the Londiniensis leans more towards Aristotle than towards Plato. It would be pointless and against my purpose of approaching the Anonymus in the widest possible way. I do not deny either one irrefutable piece of evidence: Plato is the author most extendedly treated in the Londiniensis ${ }^{80}$ in its actual state. Furthermore, there is an evident parallelism between the method of division, which in the Phaedrus Plato attributes to Hippocrates $^{81}$, and the way in which the author of the Londiniensis proceeds when he

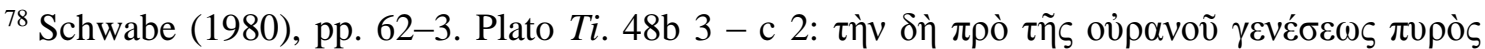

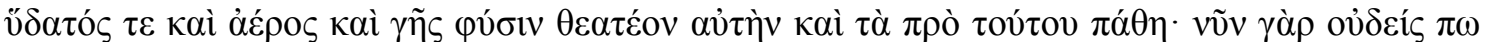

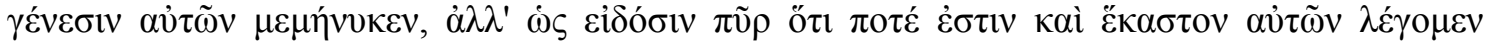

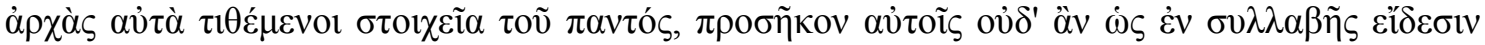

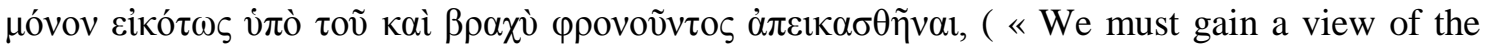
real nature of fire and water, air and earth, as it was before the birth of Heaven, and the properties they had before that time; for at present no one has yet declared their generation, but we assume that men know what fire is, and each of these things, and we call them principles and presume that they are elements of the Universe, although in truth the do not so much as deserve to be likened with any likelihood, by the man who has even a grain of sense, to the class of syllables »). Transl. Bury (1961), p. 111. Cfr. also Plato Ti. 54d 6; 55a 8 - b 4; 57c 9; 56b 5; 61a 7.

${ }^{79}$ Plato Cra. 424d 3; Tht. 201e - 206b, Sph. 252b 3; Plt. 278d 1. Schwabe (1980), pp. 68-9 n. 36.

${ }^{80} \mathrm{D}$. Manetti judges the contents of the columns devoted to Plato as appertaining to the Platonic-Academic tradition in a wide sense, and in some way, connected with the medical dogmatic tradition, which traces in turn a line that extends to Herophilus. Cfr. Manetti (2003), p. 336.

${ }^{81}$ Plato Phdr. 269c-272a. The reference is linked to a particular method which Phaedrus endorses as a necessary condition for scientific knowledge. The value of such method resides in the fact of its being applicable to the knowledge of an object ( $\varphi v ́ \sigma ı)$ whatsoever; and as far as the medical art is concerned, then also to the body. For the variety of meanings that the term

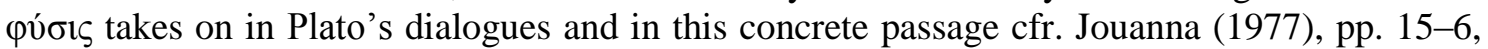
22; (1992), p. 89; (2012f), pp. 325, 328. What does this method consist of? Many scholars have provided insight into this query looking for the cornerstones of Plato's epistemology. Jouanna (1993), p. 64. In short, it is agreed that the backbone of the procedure abides in the division or diaeresis ( $\left.\delta \imath_{\alpha i} \rho \varepsilon \sigma 1 \zeta\right)$. The task is basically bound to the decomposition of the body, to divide the body in its different $\varepsilon$ ' $\delta \eta$, this meaning "typologies" or "kinds". At Phdr. 271a 7 Plato claims

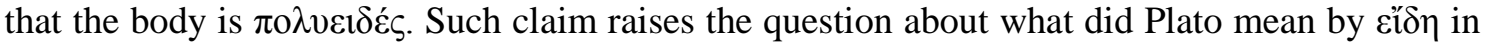
that particular context (presumably something like "type, constitution type, etc."). The method ascribed to Hippocrates is to do with the classification of the different constitution types in order to establish a coherent causal link between such constitutions and the kinds of food or remedies that suit each one the most. Therefore Hippocrates's method in the Phaedrus is neither meteorological nor cosmological, but causal. Jouanna (1977), pp. 25-6. 
defines the different kinds of affection $(\pi \dot{\alpha} \theta \mathrm{o} \varsigma)$ in the first section of the papyrus ${ }^{82}$. But of no minor import to the issue at hand, the Aristotelian imprint on the Londiniensis papyrus from a terminological angle, is that cols. XVII, 44 - XVIII, 1 disclose another concern which has to do with the usage of the word $\pi \varepsilon \rho i \tau \tau \omega \mu \alpha$ to delineate part of Plato's etiology. A look at any index of the Timaeus reveals that $\pi \varepsilon \rho i ́ \tau \tau \omega \mu \alpha$ (a typical Aristotelian lexical item $)^{83}$ does not occur in any Platonic dialogue. Why does it occur in the papyrus? It could be another telling example accounting for the scribe's indirect access to the authors with whom he was dealing.

In addition to this terminological meddling of the term $\pi \varepsilon \rho i \tau \tau \omega \mu \alpha$ in the report on Plato, it is worth noting that the theory of the physician called Herodicus in col. IX, 20 - 36 also featured the same concept, which, endorses once again the possibility that the scribe relied on an Aristotelian source inasmuch as - for chronological reasons Herodicus could hardly have drawn the word $\pi \varepsilon \rho i ́ \tau \tau \omega \mu \alpha$ from Aristotle ${ }^{84}$. In view of this, the place that Herodicus occupies in the doxographical section of the Anon. Lond. would depend on the entire subjectivity of the scribe, or on the placement in the Aristotelian source where the scribe might have found the description of Herodicus's theory of illness.

Besides these arguments of lexical order, it seems to be all the less accidental and the more important to stress that all the authors mentioned in the second section are contemporaries of Aristotle or lived before the $4^{\text {th }}$ century $\mathrm{BC}^{85}$.

From all the points set out above, it is not too far-fetched to affirm that, leaving to one side the many other sources, the contents of the second section of the Londiniensis seem to hinge upon a work with a clear Aristotelian slant.

${ }^{82}$ Dorandi (2016), p. 202 n. 16. I avoid from pronouncing myself about the first section in the papyrus, it suffices to say that I have not found explicit evidence that the first four columns preserved in the Anonymus, those concerning the definitions of $\pi \alpha$ ó $\mathrm{o}_{\zeta}$ and other terms related to being sized by an affliction, can in point of fact be traced to some known medical work.

${ }^{83}$ Nelson (1909), p. 105; Jouanna (2012a), p. 7.

${ }^{84}$ Cfr. Kollesch (1989), p. 197.

${ }^{85}$ Cfr. Ricciardetto (2014), p. XXXII; (2016), p. LIX. 


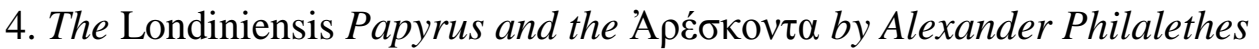

I shall go on to expound the second part of the claim that I set out in the beginning; that while part of the doxographical section in the Londiniensis papyrus could be shaped according to an Aristotelian textual source, another part, especially the columns devoted mainly to discuss physiological issues (roughly, the third section of the Lon-

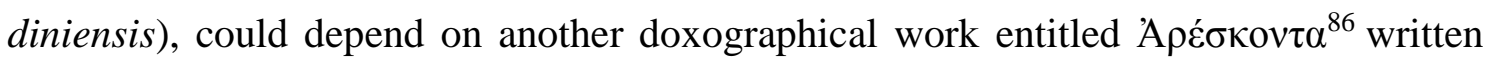
by Alexander Philalethes $(50 \mathrm{BC}-25 \mathrm{CE})^{87}$.

To shore up the second part of my general contention, I take up the last reason above as the nub of the argument that follows. Thus, while the theories of the authors that the scribe reviews in the second section of the Londiniensis are almost never criticised, those of the physicians in the third section are thoroughly confounded ${ }^{88}$. Moreover, the third section brings about a significant change in the model of reference as compared to the second. The scribe introduces the arguments of much later physicians than all the authors reviewed theretofore, and addresses their ideas with a higher level of personal involvement ${ }^{89}$. In being the most recent doctor cited in the papyrus, Alexander Philalethes figures as terminus post quem of the Anon. Lond.

However, another detail which, as far as I know, has gone unnoticed confirms my position: the multiple references to Hellenistic doctors and the information about medical schools provided in the third section (Herophilus ${ }^{90}$, Erasistratus ${ }^{91}$, the

${ }^{86}$ In almost five books (today lost) according to Galen De diff. puls. IV 4 - 5 [VIII pp. 725, 17 732, 7 K.]. Cfr. von Staden (1989), pp. 533 n. 9, 538. Alexander Philalethes (A $\lambda \varepsilon \dot{\xi} \xi \alpha v \delta \rho \circ \varsigma$ ó $\Phi 1 \lambda \alpha \lambda \eta \dot{\eta} \theta \varepsilon 10 \varsigma)$ is mentioned in cols. XXIV, 31; XXXV, 22, [54]; XXXIX, 1.

${ }^{87}$ Regardless of being disciple of Asclepiades of Bythinia Alexander reached the highest position in the Herophilean school. For a detailed portrait on Alexander Philalethes see the monographic chapter devoted to him in von Staden (1989).

${ }^{88}$ In general, one gets the impression that the author of Anon. Lond. has Plato and Aristotle in high esteem, while considers Erasistratus, Herophilus and Asclepiades as dialectical adversaries. Cfr. Manetti (1996), pp. 298, 300; (1999), p. 141; Ricciardetto (2016), pp. CXIV - CXVII.

89 Jouanna (2016), p. 9; Ricciardetto (2016), p. XCIX.

${ }^{90}$ Cfr. cols. XXI, 21; XXVIII, 46; XXXVI, 47. Herophilus of Chalcedon $(330-260$ BC) is credited with having been Praxagoras's pupil, presumably on Cos. Steckerl (1958), p. 62; Vegetti (1984), p. 459; Manetti (2014), p. 238.

${ }^{91}$ E. gr. cols. XXIII, $12-17$; XXVI, $31-48$. It is likely that the Erasistrateans mentioned by the scribe are Hicesius of Smirna (first century BC) and his heirs. Despite being abundantly quoted by Strabo, Celsus, Pliny (who preserved some fragments of his pharmacological works), Plutarch, Rufus, Caelius Aurelianus, and Galen (his bitterest opponent) it still remains unclear either when Erasistratus of Ceos lived or where (320 - 240 BC?) Cfr. von Staden (2000), p. 92. 
Empirics $^{92}$ and so forth...) could in no way have been drawn from the supposed medical doxography with which Aristotle (or Meno) is credited, basically because all these authors lived and were active when Aristotle (or Meno) had already died. Mine is in fact a slight modification of the assumption that $\mathrm{H}$. Diels set forth ${ }^{93}$. Diels was of the opinion that the scribe of the Londiniensis papyrus had no direct access to the Aristotelian source at the basis of the doxographical section, but rather he was acquainted with Aristotelian doxography through a version of the text that he found in

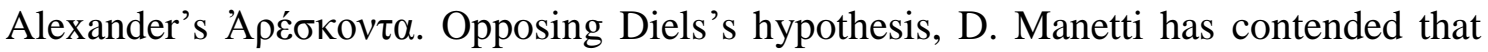
there is no apparent reason for introducing a second interface between the supposed Aristotelian doxography and the scribe.

An attestation drawn from Galen would confirm that Manetti is right on this point. In col. XXI, $21-23$, almost in the beginning of what is deemed to be the third section of the Londiniensis, the scribe wrote: 'as Herophilus meant by saying "let ap-

Erasistratus's uncles - Medios and Cleombrotes - were physicians, and his teachers were Chrysippus of Cnidos and Metrodorus. It is agreed that Erasistratus attended the courses taught by Theophrastus and Strato of Lampsacus. It is known that Erasistratus was the private doctor of the king Seleucos I Nicator. Vegetti (1984), p. 459; Byl (2011b), p. 19. Since none of his writings survive in more than fragments, we have to be content with the portraits provided by later authors or with a scarce handful of papyri that, preserved in mummies cartonnage, have handed down some passages of Erasistratus's works. This perhaps is the case with $P$. Köln VIII $327=$ P. Colon. inv. $20941=\mathrm{MP}^{3} 2380.010$. This papyrus contains fragments of a writing titled Treatise on Fevers. Cfr. Andorlini (2014), pp. 217-9. It can be consulted online at http://www.uni-koeln.de/phil-fak/ifa/NRWakademie/papyrologie/PKoeln/PK20941r.jpg (accessed 23 February 2017). Cfr. also Longrigg (1988), pp. 455 - 456.

${ }^{92}$ Col. XXXI, 26: 'E $\mu(\pi \varepsilon$ (рıкоi). In the Anon. Lond. this denomination is written by means of an abbreviation, a kind of circumflex sign above the first two letters: $\varepsilon \mu$. The Empiric medical school was founded by Philinos of Cos and Serapion of Alexandria. Marganne (2002), pp. 3634. The Empirics are credited with touting a revival of the ancient ways in the acquisition of the medical art: this is perhaps the reason why it is almost impossible to distinguish the Ancients from the Empirics at certain points in the scribe's exposition. Cfr. Grmek (1997), p. 92; Marganne (2002), p. 367. The Empiric school was founded shortly after the death of Herophilus, in a way as a schism in the medical trend that Herophilus led. von Staden (1989), p. 123. The methodology grounding the views of the Empirics could be summed up in the

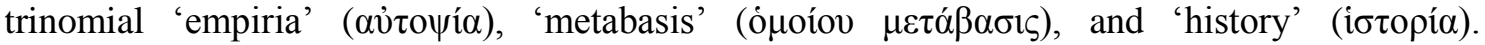
Gourevitch (1993), pp. 128-9. By definition medical Empiricism sought to minimize logic and argumentation. The Empirics rejected all kind of speculation on the causation of disease, focusing instead on the most proper and effective ways to palliate a disease and recover health. Celsus De medicina I Praef. 38 [Daremberg (1891), p. 7, 3 -4]: quia non intersit quid morbum faciat, sed quid tollat. Cfr. Vegetti (1995a), 73-6; Ricciardetto (2014), p. XLVIII.

${ }^{93}$ Diels (1893a), pp. 414-5; CPF Aristoteles 37T, p. 348. 
pearances be described as primary things even if they are not primary" ,94. The fact that Galen $^{95}$ refers to this sentence, which the scribe attributes to Herophilus ${ }^{96}$, allows us to

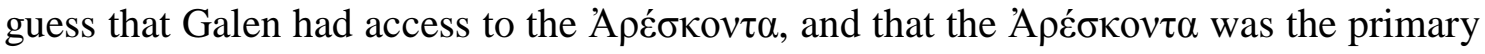
source that served as textual basis to both authors, the scribe of the papyrus and Galen.

Returning to the thread of the argument, in the paraphrase on Aristotle's On Sleep and Waking (col. XXIV, 6 - 9), the scribe of Anon. Lond. emphasises that

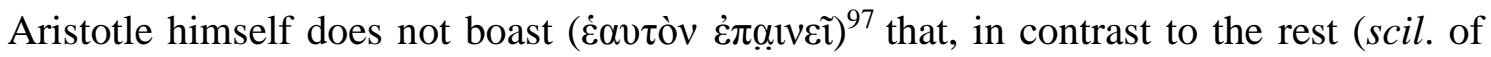
preceding or contemporary physicians), he has attempted to give an explanation for sleeping and waking, whereas the others have solely enquired into the causes of sleep, in complete disregard for those of being awake ${ }^{98}$. As H. Diels well noted in his

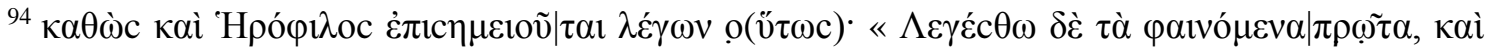

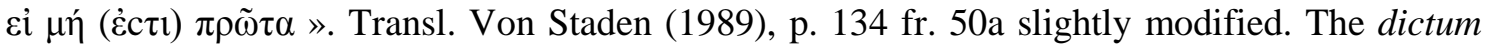
assigned to Herophilus was first addressed by H. Diels in Diels (1893b), p. 414 n. 1. According to the German philologist this motto could only be explained because of Herophilus's medical Methodism, this being why Diels contended that Herophilus was a Methodist physician. The same sentence is taken back up in Vegetti (1993), p. 90; Manetti (2003), pp. 336-7; discussed at length in Frede (2011), pp. 123-32 (I would like to thank the reviewer of this paper for hisher comment on this point); and in Manetti (2013), p. 174. The sentence is about the phenomena that anatomical dissection brings to light. The scribe makes use of Herophilus's saying in order to underpin a theoretical justification for the classification of the body parts, yet it could also be taken as the first and basic formulation of the principle on which hinges the majority of the arguments the scribe will expound hereafter in the third section. There must be some reasons accounting theoretically ( $\lambda$ ó $\omega \omega t \theta \varepsilon \omega \rho \eta \tau \grave{\alpha}$ ) for the phenomena, no doubt, but these alone do not suffice nor are they valid enough to provide a full account of worldly phenomena.

${ }^{95}$ Galen Meth. med. II 5 [X 107, 15 - 16 K.]. In the same treatise Galen uses a very similar sentence to reject Herophilus's arguments, which shows the manipulation of the information in the sources that the scribe used according to his own explanatory purposes. Frede (2011), pp. 12831.

${ }^{96}$ M. Wellmann contended instead that the Londiniensis constituted the principal source that Galen consulted for his commentaries. Cfr. Wellmann (1922), pp. 419, 421.

${ }^{97}$ Both D. Manetti and A. Ricciardetto translate col. XXIV, 6 in the negative, so did W. H. S. Jones. Cfr. Jones (1947), p. 93: 'yet'; Manetti in CPF Aristoteles 22T, p. 308: 'Eppure Aristotele (non) si loda'; Ricciardetto (2014), p. 19; (2016), p. 32: '(Mais en verité) Aristote (ne) se félicite (pas)'. In their opinion, the scribe wrote that Aristotle did not boast himself for having enquired also on the causes of the wake. The choice could be due to the fact that they take (like

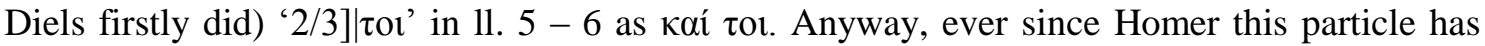
been employed to introduce or to mark a personal objection. Cfr. Liddell - Scott (1996), p. 860 s.v. Kaí $\tau$ ol.

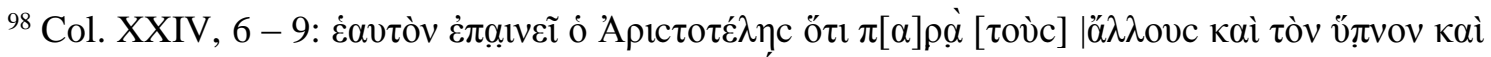

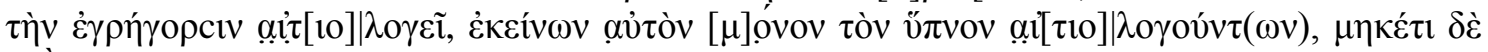

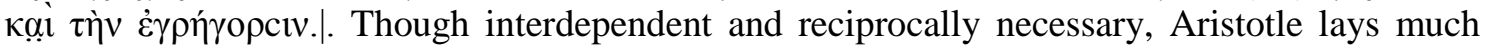
stress on affirming that sleep and waking cannot be given at once, for the first affection precludes the second and vice versa. We should like to point out in this effect that, although the supposed observations in cetaceans of his own day (e.g. Aristotle Resp. XII 476b 20-21), Aris- 
edition $^{99}$, such endorsement cannot be found in the text of On Sleep and Waking, nor the

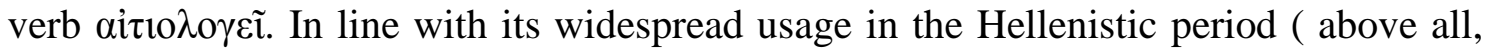

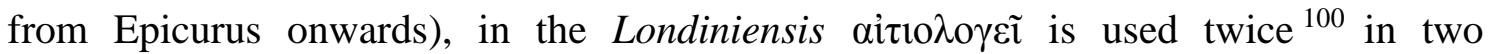

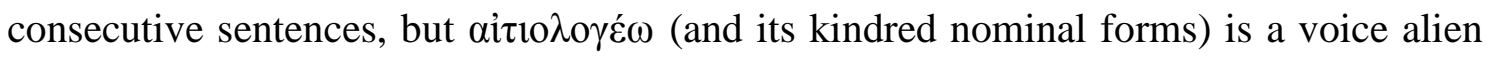
to the Corpus Aristotelicum ${ }^{101}$, or at least this is revealed by a look at Greek lexicons. Wherefore, apart from other possible explanations, it could be an addition resulting from the scribe's free will — an addition that would serve to increase the multiple arguments for the autographical nature of the Anon. Lond.; or else, and I tend more towards this second interpretation, the addition to the Aristotelian text might indicate

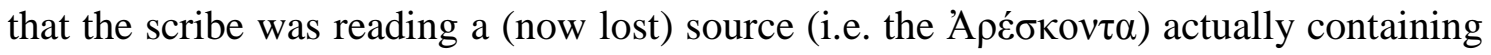
such remark.

Jordi Crespo Saumell Universitá degli Studi di Cagliari

totle's claim would be in conflict with the so-called Unihemispheric Slow-wave Sleep observed in many species, including mammals like dolphins. The difference in the explicative paradigms does not permit a straight rejection of Aristotle's view (it must be borne in mind that to Aristotle sleep is mainly to do with the heart, and to a lesser extent, with the brain); but, for our present interest, we should add that modern biology has proved that in some species both, sleep and waking, can take place simultaneously.

${ }^{99}$ Diels (1893a), p. 43: Aristoteles iu servatis libri nihil eiusmodi dixit. Cfr. also Beckh - Spät (1896), p. 35 n. 2; Jones (1947), pp. 92-3; CPF Aristoteles 22T, pp. 310-1.

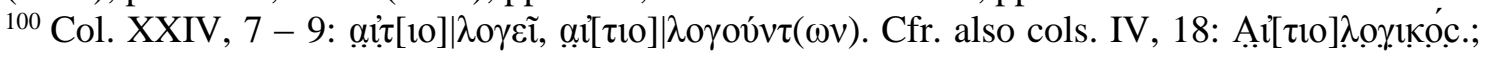

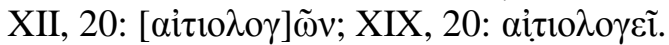

${ }^{101}$ I am thankful to Dr. J. Aoiz and Dr. D. Deniz (Universidad de Caracas) for their piece of advice in this sense. 


\section{Bibliography}

\section{1) Editions, Partial Editions, and Translations of the Anonymus Londiniensis}

Beckh, Heinrich and Spät, Franz. 1896. Auszüge eines Unbekannten aus Aristoteles - Menons Handbuch der Medizin und aus Werken änderer alter Aerzte. Berlin: G. Reimer.

CPF Aristoteles 22T = Manetti, Daniela. 1989. 'De somno et vigilia 3.' In Corpus dei papiri filosofici greci e latini. Parte I Autori Noti vol. 1* (Florence: L. S. Olschki, 1989), pp. 307-11.

$C P F$ Aristoteles 37T = Manetti, Daniela. 1989. 'Iatrica sive Collectio medica.' In Corpus dei papiri filosofici greci e latini. Parte I Autori Noti vol. 1* (Florence: L. Olschki, 1989), pp. 34551.

CPF Hippo Crotoniates 1T = Manetti, Daniela. 1992. 'Hippo Crotoniates.' In Corpus dei papiri filosofici greci e latini. Testi e lessico nei papiri di cultura greca e latina, Parte I Autori Noti vol. $1^{* *}$ (Florence: L. Olschki, 1992), pp. 455-61.

CPF Plato 129T = Manetti, Daniela. 1999. 'Timaeus 42e; 73b - 84e.' In Corpus dei papiri filosofici greci e latini. Testi e lessico nei papiri di cultura greca e latina, Parte I Autori Noti vol. 1*** (Platonis Testimonia - Zeno Tarsensis) (Florence: L. S. Olschki, 1999), pp. 528 -78.

Diels, Hermann. 1893a. Anonymi Londinensis ex Aristotelis Iatriciis Menoniis et aliis medicis Eclogae. In Hermann Diels and Academiae Litterarum Regiae Borussicae, eds., Supplementum Aristotelicum III. 1. Berlin: G. Reimer. http://galen.bbaw.de/epubl/online/wa_anon_lond.php (accessed 3 January 2017).

Jones, William Henry Samuel. 1947. The Medical Writings of Anonymus Londinensis. Cambridge: Cambridge University Press. $=[$ Transl. Jones (1947) $]$.

Manetti, Daniela. 2011. Anonymus Londiniensis: De Medicina. Berlin: Bibliotheca Teubneriana.

Ricciardetto, Antonio. 2014. L'Anonyme de Londres. Édition et traduction d'un papyrus médical grec du Ier siècle. Liège: Presses Universitaires de Liège.

Ricciardetto, Antonio. 2016. L'Anonyme de Londres. P.Lit.Lond. 165, Brit. Lib. inv. 137. Un papyrus médical grec du Ier siècle après J.-C. Paris: Les Belles Lettres.

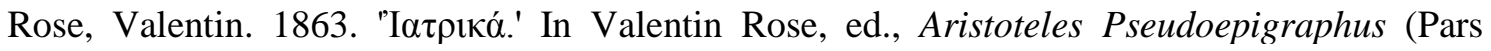
Prima). Fragmenta Aristotelica Philosophica, Leipzig: Bibliotheca Teubneriana, 1863), pp. 384-90.

2) Editions and Translations of Classical Authors, Compilations of Ancient Sources and Papyri

Alexander of Aphrodisias. 1901. In librum De sensu commentarium. In Paul Wendland (ed.), Commentaria in Aristotelem Graeca vol. III, 1. Berlin: Academiae Litterarum Regiae Borussicae. $=[$ Wendland (1901)].

'De mixtione.' In Ivo Bruns, ed., Praeter Commentaria. Scripta minora vol. II, 2 (Berlin: Academiae Litterarum Regiae Borussicae, 1892), pp. 213-38. = [Bruns (1892)].

Aristotle. 1987. Aristotelis Opera vol. III. Librorum Deperditorum Fragmenta. Berlin / New York: Walter de Gruyter. $=$ [Gigon (1987)].

1965. Historia Animalium in Three Volumes (Books 1-3) vol. I. Cambridge (MA) / London Loeb: Classical Library.

1933. Metaphysics (Books 1-9) vol. I. Cambridge (MA) / London: Loeb Classical Library. 
1957. 'On Respiration.' In Thomas Ethelbert Page and Edward Capps and William Henry Denham Rouse and Levi Arnold Post and Eric Herbert Warmington, eds., On the Soul. Parva Naturalia. On Breath (Cambridge (MA) / London: Loeb Classical Library, 1957), pp. 430-81.

1957. 'On the Soul.' In Thomas Ethelbert Page and Edward Capps and William Henry Denham Rouse and Levi Arnold Post and Eric Herbert Warmington, eds., On the Soul. Parva Naturalia. On Breath (Cambridge (MA) / London: Loeb Classical Library, 1957), pp. 8-203.

1947. The "Art" of Rhetoric. Cambridge (MA) / London: Loeb Classical Library.

1962. The Nichomachean Ethics. Cambridge (MA) / London: Loeb Classical Library.

Pseudo-Aristotle. 1965. Problemi di medicina. Milan: Istituto editoriale italiano.

Celsus. 1891. De medicina (libri I-VIII). Leipzig: Bibliotheca Teubneriana. $=[$ Daremberg (1891)].

Diogenes Laertius. 1999. Vitae philosophorum (libri I-IX) vol. I. Stuttgart / Leipzig: Bibliotheca Teubneriana. $=[$ Marcovich (1999) $]$.

Galen ${ }^{102}$. 1821. 'De constitutione artis medicae ad Patrophilum liber.' In Carl Gottlob Kühn, ed., Claudii Galeni Opera Omnia vol. I (Leipzig: Carl Cnobloch, 1821), pp. 224-304.

1821. 'De facultatibus naturalibus (libri I-III).' In Carl Gottlob Kühn, ed., Claudii Galeni Opera Omnia vol. II, Officina libraria Car. Cnoblochii, Leipzig 1821, pp. 1-214.

1823. 'De sanitate tuenda.' In Carl Gottlob Kühn, ed., Claudii Galeni Opera Omnia vol. VI (Leipzig: Carl Cnobloch, 1823), pp. 1-452.

1828. 'In Hippocratis de natura hominis commentarii (libri I-II).' In Carl Gottlob Kühn, ed., Claudii Galeni Opera Omnia vol. XV (Leipzig: Carl Cnobloch, 1828), pp. 1-173.

1914. 'Galeni In Hippocratis De natura hominis commentaria (libri III).' In Johannes Mewaldt, ed., Corpus Medicorum Graecorum vol. V 9, 1 (Leipzig: Bibliotheca Teubneriana, 1914), pp. 1-113. = $[\mathrm{CMG}$ V 9, 1 Mewaldt $]$ Availablee online at http://cmg.bbaw.de/epubl/online/cmg_05_09_01.php?p=51 (accessed 22 March 2017).

1824. 'De pulsuum differentiis (libri I-IV).' In Carl Gottlob Kühn, ed., Claudii Galeni Opera Omnia vol. VIII (Leipzig: Carl Cnobloch, 1824), pp. 493-765.

1825. 'De methodo medendi (libri I-XIV).' In Carl Gottlob Kühn, ed., Claudii Galeni Opera Omnia vol. X (Leipzig: Carl Cnobloch, 1825), pp. 1-1021.

1826. 'De simplicium medicamentorum temperamentis et facultatibus (libri VII-XI)'. In Carl Gottlob Kühn, ed., Claudii Galeni Opera Omnia vol. XII (Leipzig: Carl Cnobloch, 1826), pp. 1-377.

Hippocrates. ${ }^{103}$ 1839. 'De l'ancienne médecine.' In Émile Littré, ed., Euvres complètes d'Hippocrate vol. I (Paris / London: J. B. Baillière, 1839), pp. 570-636.

1840. 'Des airs, des eaux et des lieux.' In Émile Littré, ed., Euvres complètes d'Hippocrate vol. II (Paris / London: J. B. Baillière, 1840), pp. 12-93.

1840. 'Le pronostic.' In Émile Littré, ed., Cuvres complètes d'Hippocrate vol. II, (Paris / London: J. B. Baillière, 1840), pp. 110-91.

\footnotetext{
102 Titles are given according to the pagination and the volumes of C. G. Kühn's edition. Works subject to later editions in CMG are given below Kühn's edition.

103 Titles are given according to the pagination and the volumes of É. Littré's edition. Works subject to later editions in CMG are given below Littré's edition.
} 
1844. 'Aphorismes.' In Émile Littré, ed., Euvres complètes d'Hippocrate vol. IV (Paris / London: J. B. Baillière, 1844), pp. 458-609.

1846. 'Des humeurs.' In Émile Littré, ed., Euvres complètes d'Hippocrate vol. V (Paris / London: J. B. Baillière, 1846), pp. 476-503.

1849. 'De la nature de 1'homme.' In Émile Littré, ed., Euvres complètes d'Hippocrate vol. VI (Paris / London: J. B. Baillière, 1849), pp. 29-70.

1979. 'Nature of Man.' In George Patrick Goold, ed., former editors T. E. Page, E. Capps, W. H. D. Rouse, L. A. Post, E. H. Warmington, eds., Hippocrates vol. IV (Cambridge (MA) / London: Loeb Classical Library, 1979), pp. 2-41. = [Transl. Jones (1979)].

1849. 'Des vents.' In Émile Littré, ed., Euvres complètes d'Hippocrate vol. VI (Paris / London: J. B. Baillière, 1849), pp. 88-116.

1927. 'De flatibus.' In J. L. Heiberg, ed., Corpus Medicorum Graecorum vol. I 1, Hippocratis Indices librorum, Iusiurandum, Lex, De arte, De medico, De decent habitu, Praeceptiones, De prisca medicina, De aere locis aquis, De alimento, De liquidorum usu, De flatibus (Leipzig / Berlin: Bibliotheca Teubneriana, 1927), pp. 91-101. = [CML I 1 Heiberg] available online at http://cmg.bbaw.de/epubl/online/cmg_01_01.php?p=103 (accessed 1 March 2017).

1849. 'Des maladies, livre premier.' In Émile Littré, ed., Euvres complètes d'Hippocrate vol. VI (Paris / London: J. B. Baillière, 1849), pp. 138-205.

1849. 'Du régime.' In Émile Littré, ed., Euvres complètes d'Hippocrate vol. VI (Paris / London: J. B. Baillière, 1849), pp. 462-663.

1853. 'Des maladies des femmes.' In Émile Littré, ed., Cuvres complètes d'Hippocrate vol. VIII (Paris / London: J. B. Baillière, 1853), pp. 10-407.

Plato. 1926. 'Cratylus.' In Thomas Ethelbert Page and Edward Capps and William Henry Denham Rouse and Levi Arnold Post and Eric Herbert Warmington, eds., Cratylus. Parmenides. Greater Hippias. Lesser Hippias (Cambridge (MA) / London: Loeb Classical Library, 1926), pp. 1-192.

1961. 'Epistle II.' In Thomas Ethelbert Page and Edward Capps and William Henry Denham Rouse and Levi Arnold Post and Eric Herbert Warmington, eds., Plato with an English Translation vol. VII: Timaeus. Critias. Cleitophon. Menexenus. Epistles (Cambridge (MA) / London: Loeb Classical Library, 1961), pp. 402-23.

1960. 'Phaedrus.' In Thomas Ethelbert Page and Edward Capps and William Henry Denham Rouse and Levi Arnold Post and Eric Herbert Warmington, eds., Plato with an English Translation vol. I: Euthyphro. Apology. Crito. Phaedo. Phaedrus (Cambridge (MA) / London: Loeb Classical Library, 1960), pp. 412-579.

1961. 'Sophist.' In Thomas Ethelbert Page and Edward Capps and William Henry Denham Rouse and Levi Arnold Post and Eric Herbert Warmington, eds., Plato with an English Translation vol. VII: Theaetetus. Sophist, translated by H. N. Fowler, Loeb Classical Library, Cambridge (MA) / London 1961, pp. 264-459.

1925. 'Statesman.' In Thomas Ethelbert Page and Edward Capps and William Henry Denham Rouse and Levi Arnold Post and Eric Herbert Warmington, eds., Statesman. Philebus. Ion (Cambridge (MA) / London: Loeb Classical Library, 1925), pp. 1-196.

1961. 'Theaetetus.' In Thomas Ethelbert Page and Edward Capps and William Henry Denham Rouse and Levi Arnold Post and Eric Herbert Warmington, eds., Plato with an English Translation vol. VII: Theaetetus. Sophist (Cambridge (MA) / London: Loeb Classical Library, 1961), pp. 6-257.

1961. 'Timaeus.' In Thomas Ethelbert Page and Edward Capps and William Henry Denham Rouse and Levi Arnold Post and Eric Herbert Warmington, eds., Plato with an English 
Translation vol. VII: Timaeus. Critias. Cleitophon. Menexenus. Epistles (Cambridge (MA) / London: Loeb Classical Library, 1961), pp. 16-253. = [Transl. Bury (1961)].

Plutarch. 1961. Plutarch's Moralia in Fifteen Volumes vol. IX (697c-771e). Cambridge (MA) / London: Loeb Classical Library. = [Transl. Minar (1961)].

1971. Moralia vol. IV. Leipzig: Bibliotheca Teubneriana. $=[$ Hubert (1971)].

Thucydides. 1886. De bello peloponnesiaco (libri I-VIII) vol. I. Leipzig: Bibliotheca Teubneriana. $=[$ Transl. Boheme (1886)].

\section{3) Articles, Dictionaries, Monographs, Notes, Papers and Studies}

Abel, Karl Hans. 1957. 'Plato und die Medizin seiner Zeit.' Gesnerus: Swiss Journal of the History of Medicine and Sciences 14: 3 (1957), 94-118.

Alsina, Josep. 1989. 'Hippocrate, Sophocles et la déscription de la pest chez Thucydide.' In Gerhard Baader and Rolf Winau, eds., Die Hippokratischen Epidemien. Theorie - Praxis Tradition. Verhandlungen des $V^{e}$ Colloque International Hippocratique 10. - 15. 9. 1984 (Stuttgart: Franz Steiner, 1989) pp. 213-21.

Andorlini, Isabella. 2006. 'Il «gergo» grafico ed espressivo della ricettazione medica antica.' In Medicina e società nel mondo antico. Atti del convegno di Udine (4 - 5 Ottobre 2005) (Florence: Mondadori, 2006), pp. 142-67.

Andorlini, Isabella. 2014. 'Ippocratismo e medicina ellenistica in un trattato medico su papiro'. In Jacques Jouanna and Michel Zink, eds., Hippocrate et les hippocratismes: médecine, religion, société. Actes du XIVe Colloque International Hippocratique à la Maison de la Recherche, à l'Académie des Inscriptions et Belles-Lettres et à la Bibliothèque Interuniversitaire de Santé, les 8, 9 et 10 novembre 2012 (Paris: Académie des Inscriptions et Belles Lettres, 2014), pp. 217-29.

Bastianini, Guido. 1995. 'Tipologie dei rotoli e problemi di ricostruzione.' Papyrologica Lupiensia (Atti del V seminario internazionale di papirologia. Lecce 27 - 29 Giugno 1994) 4 (1995), 21-42.

Bertier, Janine. 1989. 'A propos de quelques résurgences des Épidémies dans les Problemata du Corpus aristotelicien.' In Gerhard Baader and Rolf Winau, eds., Die Hippokratischen Epidemien. Theorie - Praxis - Tradition. Verhandlungen des $V^{e}$ Colloque International Hippocratique 10. - 15. 9. 1984 (Stuttgart: Franz Steiner, 1989), pp. 261-69.

Bidez, Joseph and Leboucq, Georges. 1944. 'Une anatomie antique du cœur humain. Philistion de Locres et le «Timée » de Platon'. Revue des Études Grecques 57 (1944), 7-40.

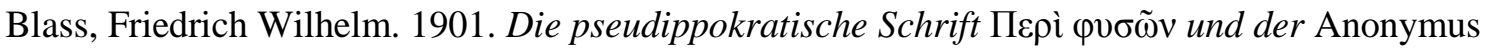
Londinensis. Hermes. Zeitschrift für klassische Philologie 36 (1901), 405-10.

Byl, Simon. 2011a. De la médecine magique et religieuse à la médecine rationnelle. Hippocrate. Paris: L'Harmattan.

Byl, Simon. 2011b. La médecine à l'époque hellénistique et romaine. Galien. Paris: L'Harmattan.

Cavallo, Guglielmo. 2008. La scrittura greca e latina dei papiri. Pisa / Rome: Fabrizio Serra.

Delatte, Louis and Rutten, Christian and Govaerts, Suzanne and Denooz, Joseph. 1984. Aristoteles Metaphysica Index Verborum. Listes de Fréquence. Hildesheim / Zürich / New York: Olms Weidmann.

Del Corso, Lucio. 2008. Oltre la scrittura. Variazioni sul tema per Guglielmo Cavallo. Paris: Centre d'études byzantines, néo - helléniques et sud-est européenes (E.H.E.S.S.). 
Diels, Hermann. 1893b. 'Über die Excerpte von Menons Iatrika in dem Londoner Papyrus 137.' Hermes. Zeitschrift für klassische Philologie 28 (1893), 403-34.

Diller, Hans. 1932. Die Überlieferung der hippokratischen Schrift ПEPI AEP $\Omega N$ Y $\triangle A T \Omega N$ ТОП $\Omega$ N. Philologus 13: 3 (1932), 1-190.

Dorandi, Tiziano. 2016. 'Elementi 'diairetici' nella sezione iniziale dell'Anonymus Londiniensis (P.Br.Libr. inv. 137 I-IV 17).' Papyrologica Florentina (E sì d'amici pieno. Omaggio di studiosi italiani a Guido Bastianini per il suo settantesimo compleanno) 45: 1 (2016), 199-205.

Frede, Michael. 2011. 'An anti-Aristotelian Point of Method in Three Rationalist Doctors.' In Ben Morison and Katerina Ierodiakonou ed., Episteme, etc.: Essays in Honour of Jonathan Barnes (Oxford: Oxford University Press, 2011), pp. 115-37.

Giannantoni, Gabriele. 1984. 'Su alcuni problemi circa i rapporti tra scienza e filosofia nell'età ellenistica.' In Gabriele Giannantoni, ed., La scienza ellenistica. Atti delle tre giornate di studio tenutesi a Pavia dal 14 al 16 Aprile 1982 (Pavia: Bibliopolis, 1984), pp. 39-73.

Gourevitch, Danielle. 1993. 'Le vie della conoscenza: la medicina nel mondo romano.' In Mirko Dražen Grmek, ed., Storia del pensiero medico occidentale 1. Antichità e medioevo (Rome / Bari Gius: Laterza \& Figli Spa, 1993), pp. 121-67.

Gourevitch, Danielle. 1995. 'La medicina ippocratica e l'opera delle Arie, Acque, Luoghi: breve storia della nascita e del potere di un inganno scientifico.' Medicina nei Secoli. Arte e Scienza 7: 3 (1995), 425-33.

Grmek, Dražen Grmek. 1997. Le chaudron de Médée. L'expérimentation sur le vivant dans l'Antiquité. Le Plessis - Robinson: Institut Synthélabo pour le progrès de la connaissance.

Guardasole, Alessia. 1997. Eraclide di Tarento. Frammenti. Naples: M. D’Auria.

Harrauer, Hermann. 2010. Handbuch der griechischen Paläographie. Textband. Stuttgart: A. Hiersemann.

Heitz, Emil. 1865. Die Verlorenen Schriften des Aristoteles. Leipzig: Bibliotheca Teubneriana.

Joly, Robert. 1968. 'La biologie d'Aristote.' Revue Philosophique de la France et de l'Étranger 158 (1968), 219-53.

Jones, William Henry Samuel. 1984. 'General Introduction.' In George Patrick Goold, ed., Hippocrates vol. I: Ancient Medicine. Airs, Waters, Places. Epidemics 1 and 3. The Oath. Precepts. Nutriment (Cambridge (MA) / London: Loeb Classical Library, 1984), pp. IX LXIX.

Jouanna, Jacques. 1977. 'La collection Hippocratique et Platon (Phèdre 269c -272a)'. Revue des Études Grecques 90: 15-28.

Jouanna, Jacques. 1988. 'Hippocrate et la santé'. Cahiers du Séminaire de Philosophie 8: 17-47.

Jouanna, Jacques. 1992. Hippocrate. Paris: Arthème Fayard.

Jouanna, Jacques. 1993. 'La nascita dell'arte medica occidentale'. In Mirko Dražen Grmek, ed., Storia del pensiero medico occidentale 1. Antichità e medioevo (Rome / Bari Gius: Laterza \& Figli Spa, 1993), pp. 3-72.

Jouanna, Jacques. 1996. 'Hippocrate et les Problemata d'Aristote: Essai de comparaison entre Airs, eaux, lieux c. 10; Aphorismes III, 11-14 et Problemata I 8-12 et 19-20'. In Renate Wittern and Pierre Pellegrin, eds., Medizin der Antike. Hippokratische Medizin und antike Philosophie. Verhandlungen des VIII. International Hippokrates-Kolloquiums in Kloster Banz/Staffelstein vom 23. bis 28. September 1993 vol. I (Hildesheim / Zürich / New York: Olms Weidmann, 1996), pp. 273-93. 
Jouanna, Jacques. 2012a. 'Egyptian Medicine and Greek Medicine'. In Philip Van der Eijk, ed., Greek Medicine from Hippocrates to Galen. Selected Papers (Leiden / Boston: Brill, 2012), pp. 3-20.

Jouanna, Jacques. 2012b. 'Politics and Medicine. The Problem of Change in Regimen in Acute Diseases and Thucydides (Book 6)'. In Philip Van der Eijk, ed., Greek Medicine from Hippocrates to Galen. Selected Papers (Leiden / Boston: Brill, 2012), pp. 21-38.

Jouanna, Jacques. 2012c. 'Rhetoric and Medicine in the Hippocratic Corpus. A Contribution to the History of Rhetoric in the Fifth Century'. In Philip Van der Eijk, ed., Greek Medicine from Hippocrates to Galen. Selected Papers (Leiden / Boston: Brill, 2012), pp. 39-53.

Jouanna, Jacques. 2012d. 'Air, Miasma and Contagion in the Time of Hippocrates and the Survival of Miasmas in Post-Hippocratic Medicine (Rufus of Ephesus, Galen and Palladius)'. In Philip Van der Eijk, ed., Greek Medicine from Hippocrates to Galen. Selected Papers (Leiden / Boston: Brill, 2012), pp. 121-36.

Jouanna, Jacques. 2012e. 'Dietetics in Hippocratic Medicine: Definition, Main Problems, Discussion'. In Philip Van der Eijk, ed., Greek Medicine from Hippocrates to Galen. Selected Papers (Leiden / Boston: Brill, 2012), pp. 137-53.

Jouanna, Jacques. 2012f. 'Galen's Reading of the Hippocratic Treatise The Nature of Man: The Foundation of Hippocratism in Galen'. In Philip Van der Eijk, ed., Greek Medicine from Hippocrates to Galen. Selected Papers (Leiden / Boston: Brill, 2012), pp. 313-33.

Jouanna, Jacques. 2012g. 'The Legacy of the Hippocratic Treatise The Nature of Man: the Theory of the Four Humours'. In Philip Van der Eijk, ed., Greek Medicine from Hippocrates to Galen. Selected Papers (Leiden / Boston: Brill, 2012), pp. 335-59.

Jouanna, Jacques. 2016. 'Mais qui est donc l'auteur de l'Anonyme de Londres?'. Paper read and handed out during the DIGMEDTEXT. Final Conference on Greek Medical Papyri. Text, Context, Hypertext held at the Università degli Studi di Parma, Parma 2 - 4 November 2016.

Jouanna, Jacques and Grmek, Mirko. 2000. 'Notice'. In Épidemies V et VII (Paris: Les Belles Lettres, 2000), pp. VII-CXLIV.

Kenyon, Frederic George. 1892. 'A Medical Papyrus in the British Museum.' Classical Review 6 (1892), 237-40.

Kollesch, Jutta. 1989. 'Die diätetischen Aphorismen des sechten Epidemiensbuches und Herodikos von Selymbria.' In Gerhard Baader and Rolf Winau, eds., Die Hippokratischen Epidemien. Theorie - Praxis - Tradition. Verhandlungen des $V^{e}$ Colloque International Hippocratique 10. - 15. 9. 1984 (Stuttgart: Franz Steiner, 1989), pp. 191-98.

Kudlien, Fridolf. 1989. 'Hippokrates-Rezeption im Hellenismus.' In Gerhard Baader and Rolf Winau, eds., Die Hippokratischen Epidemien. Theorie - Praxis - Tradition. Verhandlungen des $V^{e}$ Colloque International Hippocratique 10. - 15. 9. 1984 (Stuttgart: Franz Steiner, 1989), pp. 355-76.

Kühn, Josef Hans and Fleischer, Ulrisch and Alpers, Karl. 1989. Index Hippocraticus (cui elaborando interfuerunt sodales Thesauri Linguae Graecae Hamburgensis) Göttingen: Vandenhoeck \& Ruprecht.

Laín Entralgo, Pedro. 1982. La medicina hipocrática. Madrid: Alianza.

Liddell, Henry George and Scott, Robert. 2006. A Greek-English Lexicon (with a Revised Supplement). Oxford: Clarendon Press.

Lloyd, Geoffrey Ernest Richard. 1968. The Role of Medical and Biological Analogies in Aristotle's Ethics. Phronesis 13 (1968), 68-83.

Lloyd, Geoffrey Ernest Richard. 2003. In the Grip of Disease. Studies in the Greek Imagination. Oxford: Oxford University Press. 
Longrigg, James. 1988. 'Anatomy in Alexandria in the Third Century B.C.' The British Journal for the History of Science 21 (1988), 455-88.

Longrigg, James. 1995. 'Medicine and the Lyceum.' In Philip Van der Eijk and Herman Horstmanshoff and Peter H. Schrijvers, eds., Ancient Medicine in its Socio-Cultural Context. Papers Read at the Congress Held at Leiden University 13-15 April 1992 vol. II (Amsterdam: Rodopi, 1995), pp. 431-45.Manetti, Daniela. 1986. 'Note di lettura dell'Anonimo Londinese. Prolegomena ad una nuova edizione.' Zeitschrift für Papyrologie und Epigraphik 63 (1986), 57-74.

Manetti, Daniela. 1990. 'Doxographical Deformation of Medical Tradition in the Report of the Anonymus Londinensis on Philolaus.' Zeitschrift für Papyrologie und Epigraphik 83 (1990), 219-33.

Manetti, Daniela. 1994. 'Autografi e incompiuti : il caso dell'Anonimo Londinese P. Lit. Lond. 165.' Zeitschrift für Papyrologie und Epigraphik 100 (1994), 47-58.

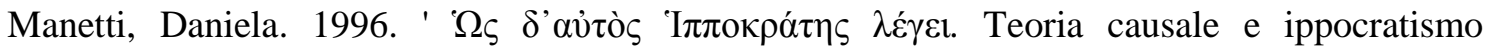
nell'Anonimo Londinese (VI 43ss.).' In Renate Wittern and Pierre Pellegrin, eds., Medizin der Antike. Hippokratische Medizin und antike Philosophie. Verhandlungen des VIII. International Hippokrates-Kolloquiums in Kloster Banz/Staffelstein vom 23. bis 28. September 1993 vol. I (Hildesheim /Zürich / New York: Olms Weidmann, 1996), pp. 295-310.

Manetti, Daniela. 1999. 'Aristotle and the Role of Doxography in the Anonymus Londinensis (PBrLibr inv.137).' In Philip Van der Eijk, ed., Ancient Histories of Medicine. Essays in Medical Doxography and Historiography in Classical Antiquity (Leiden / Boston / Köln: Brill, 1999), pp. 95- 43.

Manetti, Daniela. 2003. 'Il ruolo di Asclepiade di Bitinia nell'Anonimo Londinese.' In Antonio Garzya and Jacques Jouanna, eds., Transmission et ecdotique des textes médicaux grecs. Actes du IV Colloque International (Paris, 17-19 mai 2001) (Naples: M. D’Auria, 2003), pp. 335-47.

Manetti, Daniela. 2013. 'Levels of Authorial Presence in Anonymus Londiniensis (P.Brit. Libr. inv. 137)'. Trends in Classics 5 (2013), 159-78.

Manetti, Daniela. 2014. 'Alle origini dell'Ippocratismo: fra IV e III sec.' In Jacques Jouanna and Michel Zink, eds., Hippocrate et les hippocratismes: médecine, religion, société. Actes du XIVe Colloque International Hippocratique à la Maison de la Recherche, à l'Académie des Inscriptions et Belles-Lettres et à la Bibliothèque Interuniversitaire de Santé, les 8, 9 et 10 novembre 2012 (Paris: Académie des Inscriptions et Belles Lettres, 2014), pp. 231-51.

Manetti, Daniela. 2016. 'La sezione sulle definizioni dell'Anonimo Londinese (P.Br.Libr. inv. 137).' Papyrologica Florentina (E sì d'amici pieno. Omaggio di studiosi italiani a Guido Bastianini per il suo settantesimo compleanno) 45: 2 (2016), 525-31.

Marenghi, Gerardo. 1961. 'Aristotele e la medicina greca.' Istituto Lombardo. Accademia di Scienze e Lettere 95: 141-61.

Marganne, Marie - Hélène. 2002. L"École Médicale" d'Alexandrie et son influence sur la médecine de l'Égypte gréco-romaine. Medicina nei Secoli. Arte e Scienza 14: 2 (2002), 359-82.

Miller, Harold. 1962. 'The Aetiology of Disease in Plato's Timaeus.' Transactions and Proceedings of the American Philological Association 93 (1962), 175-87.

Moraux, Paul. 1951. Les listes anciennes des ouvrages d'Aristote. Louvain: Éditions Universitaires.

Nelson, Axel. 1909. Die Hippokratische Schrift ПЕPI $\Phi Y \Sigma \Omega$ N. Text und studien. Uppsala: Almqvist \& Wiksells Buchdruckerei.

Nutton, Vivian. 1989. 'Hippocrates in the Renaissance.' In Gerhard Baader and Rolf Winau, eds., Die Hippokratischen Epidemien. Theorie - Praxis - Tradition. Verhandlungen des $V^{e}$ Colloque International Hippocratique 10. - 15. 9. 1984 (Stuttgart: Franz Steiner,1989), pp. 42039. 
Nutton, Vivian. 1990. 'The Patient's Choice: A New Treatise by Galen.' The Classical Quarterly 40: 1 (1990), 236-57.

Nutton, Vivian. 1996. s.v. 'Anonymus Londinensis.' In Hubert Cancik and Helmuth Schneider, eds., Der Neue Pauly vol. I (Stuttgart / Weimar: J. B. Metzler, 1996), pp. 718-19.

Nutton, Vivian. 2004. Ancient Medicine. London / New York: Routledge.

Pearcy, Lee. 1993. Medicine and Rhetoric in the Period of the Second Sophistic. In Wolfgang Haase and Hildegar Temporini, eds., Aufstieg und Niedergang der Römischen Welt II 37, 1 (Berlin / New York: Walter de Gruyter \& Co., 1993), pp. 445-56.

Pino Campos, Luís Miguel and Hernández González, Justo Pedro. 2008. 'En torno al significado original del vocablo griego epidēmía y su identificación con el latino pestis.' Dynamis. Acta Hispanica ad Medicinae Scientiarumque Historiam Illustrandam 28 (2008), 199-215.

Poschenrieder, Franz. 1887. Die naturwissenschaftlichen Schriften des Aristoteles in ihrem Verhältnis zu den Büchern der hippokratischen Sammlung, Programm der königlichen Studienansalt Bamberg, Bamberg 1887.

Raeder, Hans. 1931. s.v. 'Menon.' In Wilhelm Kroll, ed., Realencyclopädie der Classischen Altertumswissenschaft XV, 1 (Stuttgart: A. Druckenmüller, 1931), p. 927.

Roselli, Amneris. 1989. Epidemics and Aphorisms: Notes on the History of Early Transmission of Epidemics. In Gerhard Baader and Rolf Winau, eds., Die Hippokratischen Epidemien. Theorie - Praxis - Tradition. Verhandlungen des Ve Colloque International Hippocratique 10. 15. 9.1984 (Stuttgart: Franz Steiner, 1989), pp. 182-90.

Schuhl, Pierre Maxime. 1960. 'Platon et la Médecine.' Revue des Études Grecques 73 (1960), 73-9.

Schwabe, Wilhelm. 1980. "Mischung" und "Element" im Griechischen bis Platon.Wort- und begriffsgeschichtliche Untersuchungen, insbesondere zur Bedeutungsentwicklung von Stoicheion. Bonn: H. Grundmann.

Squillace, Giuseppe. 2013. 'Erofilo ed Erasistrato e il recupero di testi medici per la Biblioteca di Alessandria.' In Monica Berti and Virgilio Costa, eds., Ritorno ad Alessandria. Storiografia antica e cultura bibliotecaria: tracce di una relazione perduta. Atti del Convegno Internazionale Università di Roma Tor Vergata 28-29 Novembre 2012 (Rome: Tored, 2013), pp. 155-78.

Steckerl, Fritz. 1945. 'Plato, Hippocrates, and the Menon Papyrus.' Classical Philology 40: 3 (1945), 166-80.

Steckerl, Fritz. 1958. The Fragments of Praxagoras of Cos and his School. Leiden: E. J. Brill.

Tacchini, Isabella. 1996. 'La medicina.' In Lo spazio letterario della Grecia antica vol. III. Cronologia e bibliografia della letteratura greca (Rome: Salerno Editrice, 1996), pp. 690-725.

Thivel, Antoine. 2001. 'La doctrine d' Hippocrate dans 1' Anonyme de Londres.' In Michel Woronoff and Simone Follet and Jacques Jouanna, eds., Dieux, héros et médecins grecs, Hommage à Fernand Robert (Besançon: Institut des Sciences et Techniques de l'Antiquité, 2001), pp. 197-209.

Van der Eijk, Philip. 1995. 'Aristotle on "Distinguished Physicians" and on the Medical Significance of Dreams.' In Philip Van der Eijk, Herman Horstmanshoff and Peter Schrijvers, eds., Ancient Medicine in its Socio-Cultural Context. Papers Read at the Congress Held at Leiden University 13-15 April 1992 vol. II (Amsterdam: Rodopi, 1995), pp. 447-59.

Van der Eijk, Philip. 1999. 'On Sterility ('HA X'), A Medical Work by Aristotle?' The Classical Quarterly 49: 2 (1999), 490-502.

Van der Eijk, Philip. 2005. 'The Heart, the Brain, the Blood and the Pneuma: Hippocrates, Diocles and Aristotle on the Location of Cognitive Processes.' In Philip Van der Eijk, ed., 
Medicine and Philosophy in Classical Antiquity (Cambridge: Cambridge University Press, 2005), pp. 119-36.

Van der Eijk, Philip. 2014. 'Hippocrate aristotélicien.' In Jacques Jouanna and Michel Zink, eds., Hippocrate et les hippocratismes: médecine, religion, société. Actes du XIVe Colloque International Hippocratique à la Maison de la Recherche, à l'Académie des Inscriptions et Belles-Lettres et à la Bibliothèque Interuniversitaire de Santé, les 8, 9 et 10 novembre 2012 (Paris: Académie des Inscriptions et Belles Lettres,2014), pp. 347-69.

Vegetti, Mario. 1984. 'La scienza ellenistica: problemi di epistemologia storica.' In Gabriele Giannantoni, ed., La scienza ellenistica. Atti delle tre giornate di studio tenutesi a Pavia dal 14 al 16 Aprile 1982 (Pavia: Bibliopolis, 1984), pp. 427-70.

Vegetti, Mario. 1993. 'Tra il sapere e la pratica: la medicina ellenistica.' In Mirko Dražen Grmek, ed., Storia del pensiero medico occidentale 1. Antichità e medioevo (Rome / Bari: Gius. Laterza \& Figli Spa, 1993), pp. 73-120.

Vegetti, Mario. 1995a. 'Galeno e la rifondazione della medicina.' Dynamis. Acta Hispanica ad Medicinae Scientiarumque Historiam Illustrandam 15 (1995), 67-101.

Vegetti, Mario. 1995b. La Medicina in Platone. Venice: Il Cardo.

Von Staden, Heinrich. 1989. Herophilus. The Art of Medicine in Early Alexandria. Cambridge: Cambridge University Press.

Von Staden, Heinrich. 2000. 'Body, Soul, and Nerves: Epicurus, Herophilus, Erasistratus, the Stoics, and Galen'. In John Wright and Paul Potter, eds., Psyche and Soma, (Oxford: Clarendon Press, 2000), pp. 79-117.

Wellmann, Max. 1922. 'Der Verfasser des Anonymus Londinensis.' Hermes. Zeitschrift für klassische Philologie 57 (1922), 396-429.

Withington, Edward Theodore. 1929. 'Medicine: The 'IATPIKA of Menon. Anonymi Londinensis Iatrica.' In J. U. Powell, E. A. Barber (eds.), New Chapters in the History of Greek Literature. Second Series, Clarendon Press, Oxford 1929, pp. 183 - 188. 